\title{
zis $\begin{array}{ll}\text { Research Square } & \text { They should not be considered conclusive, used to inform clinical practice, } \\ \text { or referenced by the media as validated information. }\end{array}$
}

\section{Characterization and genetic diversity of Helicobacter pylori type IV secretion system components, Cagl and CagN and its association with clinical outcomes among Iranian patients}

\section{Yasaman Azizimoghaddam}

Shaheed Beheshti University of Medical Sciences Research Institute for Gastroenterology and Liver

Diseases

\section{Sadaf Kermanpour}

Shaheed Beheshti University of Medical Sciences Research Institute for Gastroenterology and Liver

Diseases

Nasrin Mirzaei

Shaheed Beheshti University of Medical Sciences Research Institute for Gastroenterology and Liver

Diseases

\section{Hamidreza Houri}

Shaheed Beheshti University of Medical Sciences Research Institute for Gastroenterology and Liver Diseases

Abbas Yadegar ( $\square$ a.yadegar@sbmu.ac.ir)

Shaheed Beheshti University of Medical Sciences https://orcid.org/0000-0002-2135-7581

\section{Navin Kumar}

Gautam Buddha University

Hamid Asadzadeh Aghdaei

Shaheed Beheshti University of Medical Sciences Research Institute for Gastroenterology and Liver

Diseases

Mohammad Reza Zali

Shaheed Beheshti University of Medical Sciences Research Institute for Gastroenterology and Liver Diseases

\section{Research}

Keywords: Helicobacter pylori, Cagl, CagN, cagPAl, genetic diversity, virulence genotype

Posted Date: September 1st, 2020

DOI: https://doi.org/10.21203/rs.3.rs-64096/v1 
License: (c) (i) This work is licensed under a Creative Commons Attribution 4.0 International License. Read Full License 


\section{Abstract \\ Background}

A number of cagPAl genes in $\mathrm{H}$. pylori genome was proposed to be the most probably evolved under a diversifying selection and evolutionary pressure. Among them, Cagl and CagN are described as a part of the two different-operon of cagPAl that are involved in the T4SS, but the definite association of these factors with clinical manifestations is unclear.

\section{Methods}

A total of $70 \mathrm{H}$. pylori isolates were obtained from different gastroduodenal pateints. All isolates were examined for the presence of primary $H$. pylori virulence genes by PCR analysis. Direct DNA sequence analysis was performed for the $\mathrm{cag} /$ and $c a g N$ genes. The results were compared with reference strain.

\section{Results}

The cagl, cagN, cagA, cagL, vacA s1m1, vacA s1m2, vacA s2m2, babA2, sabA and dupA genotypes were detected in $80 \%, 91.4 \%, 84 \%, 91.4 \%, 32.8 \%, 42.8 \%, 24.4 \%, 97.1 \%, 84.3 \%$, and $84.3 \%$ of the total isolates, respectively. The most variable codon usage in cag/ was observed at residues 20 to 25,55 to $60,94,181$ to 199,213 to 221,241 to 268 , and 319 to 320 , while the most variable codon usage in CagN hypervariable motif (CagNHM) was observed at residues 53 to 63. This CagNHM region is postulated to contain GDEEITEEEKK sequence in the P12 reference strain. Sequencing data analysis of cagN revealed a conserved hypothetical hexapeptide repeat (EAKDEN/K) in residues of 278-283 among six H. pylori isolates, which needs further studies to evaluate its putative function.

\section{Conclusion}

The present study demonstrated a high prevalence of $c a g /$ and $c a g N$ genes among Iranian H. pylori isolates with gastroduodenal diseases. Furthermore, no significant correlation between $\mathrm{cag} /$ and $\mathrm{cagN}$ variants and clinical outcomes was observed. However, all patients had high prevalence of cagPAl genes including cagl, cagN, cagA and cag $L$ that indicates more potential role of these genes in disease outcome.

\section{Introduction}

Helicobacter pylori (H. pylori) is a Gram-negative, microaerophilic bacterium that can be chronically colonized in the human stomach. This organism infects more than $50 \%$ of the world's population, and is the main cause of chronic active gastritis, gastric and duodenal ulcers, mucosa-associated lymphoid tissue (MALT) lymphoma and gastric adenocarcinoma [1, 2]. Although $H$. pylori is recognized as the 
major risk factor for development of gastric malignancy, most $H$. pylori-infected individuals are asymptomatic and may tolerate the presence of this organism in their stomach lifelong $[3,4]$. The severity of $\mathrm{H}$. pylori-induced gastric diseases seems to be associated with several parameters, including host genetic polymorphism, inflammatory responses, environmental factors, and bacterial virulence genotype $[5,6]$.

H. pylori is associated with high genetic variability including virulence genes due to genetic plasticity, rearrangement of DNA and, high transformation and recombination frequency. Thereby, H. pylori infected patients greatly varies in the disease progression and clinical outcomes geographically. To date, several virulence factors have been identified in the genome of $H$. pylori such as CagA, VacA, BabA, SabA, and DupA [6, 7]. CagA, an oncoprotein, is the best studied virulence-associated factor of H. pylori that is translocated into the host gastric epithelial cells via the type 4 secretion system (T4SS). The H. pylori T4SS machinery is constituted by a cluster of gene products located on an approximately $40 \mathrm{~kb}$ chromosomal region named cag Pathogenicity Island (cagPAI) [8, 9]. cagPAl encodes about 27-31 genes, by which a subset of these genes encodes the main components of the T4SS apparatus spanning bacterial membranes. Moreover, possibly 15 to 16 different proteins of the T4SS are required for translocation of CagA and peptidoglycan fragments into the host cells, and also secretion of IL-8 from gastric epithelial cells [10]. Once CagA is translocated then it modulates the host cell signaling which results the loss of membrane polarity, cell elongation, induction of inflammatory cytokines and development of gastric adenocarcinoma [11]. cagPAl encodes several unique Cag components that have no sequence similarities to any other bacterial proteins involved in T4SS. However, a number of cagPAI genes such as cagland cagN were proposed to be most probably evolved under a diversifying selection and evolutionary pressure [12]. Cagl, a small protein ( $41.5 \mathrm{kDa}$ ) encoded by cag/(cag19/hp0540) gene, does not share any sequence and topological homology to any other known proteins [13, 14], whereas CagN, a 32-35 kDa protein also termed as Cag17/HP0538 encoded by cagN gene ( $h p 0538$ ), is a poorly characterized component of the T4SS that appears to be localized to the bacterial inner membrane rather than the periplasm $[10,13,15,16]$.

There are some conflicting reports about the role of Cagl and CagN in CagA translocation, IL-8 induction from gastric epithelial cells, and $H$. pylori T4SS machinery $[15,17-21]$. Reviewing subsequent and more recent literatures have revealed that Cagl is capable of binding to $\beta 1$ integrins of the host cell and is essential for CagA translocation, and is also involved in pilus biogenesis of T4SS [22, 23]. On the other hand, deletion of $\operatorname{cagN}$ can reduce the phosphorylation degree of CagA into host cell and it is not considered as a substrate for the T4SS [15]. To understand the precise role of Cagl and CagN in CagA translocation and pathogenesis need to be further investigated. The oncogenic potential of $H$. pylori strains is associated with their virulence capacity, genetic diversity and specific sequence polymorphisms within the key genes involving in translocation and phosphorylation of T4SS effectors [24-27]. Therefore, the present study aimed to determine the prevalence of cagland cagN genes and their amino acid sequence polymorphisms in Iranian H. pylori-infected patients with various gastroduodenal diseases. The probable association between the genetic variants of $\mathrm{cag} /$ and $\mathrm{cagN}$ and other virulence genotypes of $H$. pylori with clinical consequences were also investigated. 


\section{Methods}

\section{H. pylori clinical isolates and biopsy specimens}

Seventy gastric biopsy specimens were obtained from patients with different gastroduodenal diseases who referred for upper gastroduodenal endoscopy at Research Institute for Gastroenterology and Liver Diseases, Tehran, Iran, between January 2017 and May 2019. Three antral biopsies were taken from each patient and examined for culture and histopathology. The biopsy specimens were immediately placed in transport medium containing Thioglycolate supplemented with 3\% yeast extract (Oxoid Ltd., Basingstoke, UK) and $1.3 \mathrm{~g} / \mathrm{L}$ agar (Merck, Germany). All patients gave their written informed consent under a local protocol approved by the Institutional Ethical Review Committee of Research Institute for Gastroenterology and Liver Diseases at Shahid Beheshti University of Medical Sciences (Project No. IR.SBMU.RIGLD.REC.1398.023).

\section{H. pylori culture and identification}

Biopsy specimens were carefully homogenized and inoculated onto the surface of Brucella agar plates (Merck, Germany) supplemented with 7\% (v/v) horse blood, 10\% fetal calf serum (FCS), Campylobacterselective supplement (vancomycin $2.0 \mathrm{mg}$, polymyxin $0.05 \mathrm{mg}$, trimethoprim $1.0 \mathrm{mg}$ ), and amphotericin $B$ $(2.5 \mathrm{mg} / \mathrm{l})$. The incubation was performed at $37^{\circ} \mathrm{C}$ for 3-7 days under a microaerophilic atmosphere ( $5 \%$ $\mathrm{O}_{2}, 10 \% \mathrm{CO}_{2}$ and $85 \% \mathrm{~N}_{2}$ ) in a $\mathrm{CO}_{2}$ incubator (Innova ${ }^{\circledR} \mathrm{CO}-170$; New Brunswick Scientific, USA). The suspected colonies were identified as $H$. pylori based on colony morphology, Gram staining, positive reaction for oxidase, catalase and urease tests, and also by $H$. pylori gene-specific PCR following the previously described protocols $[28,29]$. Pure cultures from confirmed isolates were kept in $0.5 \mathrm{ml}$ of Brain heart infusion (BHI) medium (Merck, Germany) containing $15 \%$ glycerol plus $20 \% \mathrm{FCS}$, and stored at $-80^{\circ} \mathrm{C}$ until further analysis.

\section{Genomic DNA extraction}

Genomic DNA was extracted from freshly harvested colonies on agar plates, using the QIAamp DNA Mini Kit (QIAGEN, Hilden, Germany) according to the manufacturer's instructions. The quality of DNA was checked by using NanoDrop ${ }^{\circledR}$ ND-1000 spectrophotometer (Thermo Fisher Scientific, USA). The extracted DNA samples were stored at $-20^{\circ} \mathrm{C}$ until PCR assay.

\section{Genotyping of $H$. pylori virulence-associated genes}

PCR analysis was performed to detect virulence target genes including cagL, cagA, vacA alleles (s1/s2 and $\mathrm{m} 1 / \mathrm{m} 2$ ), babA2, sabA and dupA genes using specific primers (Table 1). Briefly, PCR mixtures in a volume of $25 \mu \mathrm{l}$ consisted of $2 \mu \mathrm{l}$ of template DNA (approximately $200 \mathrm{ng}$ ), $0.1 \mathrm{mM}$ of each primer, $2.5 \mu \mathrm{l}$ of a 10 -fold concentrate PCR buffer, $100 \mathrm{mM}$ of deoxynucleotide triphosphates, $1 \mathrm{mM} \mathrm{MgCl}_{2}$, and $1.5 \mathrm{U}$ of Super-Taq ${ }^{T M}$ DNA polymerase (HT Biotechnology Ltd., Cambridge, UK). PCR amplifications were performed in a thermocycler (Eppendorf, Hamburg, Germany) under the following conditions: initial 
denaturation at $94^{\circ} \mathrm{C}$ for $4 \mathrm{~min}$, followed by 30 cycles of denaturation at $94^{\circ} \mathrm{C}$ for $1 \mathrm{~min}$, annealing at the indicated temperature for each reaction in Table 1 for $45 \mathrm{~s}$, extension at $72^{\circ} \mathrm{C}$ for $1 \mathrm{~min}$. A final extension step was performed at $72^{\circ} \mathrm{C}$ for 10 min to ensure full extension of the PCR products. PCR amplicons were electrophoresed on a 1.2\% TBE agarose gel, stained with ethidium bromide, and examined under a UV transilluminator. H. pylori J99 (CCUG 47164) and a no-template mixture served as positive and negative controls in each PCR experiment, respectively.

\section{Primer designation for cagl and cagN genotyping}

The NCBI GenBank database (http://www.ncbi.nlm.nih.gov/genbank/) and the DNA Data Bank of Japan (http://www.ddbj.nig.ac.jp/) were searched for all available complete and partial cag/and cagN sequences of $H$. pylori strains. Based on pairwise and multiple nucleotide sequence alignments of cagl and cagN genes from different $H$. pylori strains and using the complete relevant sequence of $H$. pylori P12 (CP001217.1) as the reference strain, two pairs of specific primers were designed from the conserved regions for detection of complete related sequences using CLC Sequence Viewer 8 software (https://www.qiagenbioinformatics.com/). The selected primer target sites were compared to all available complete and partial cagland cagN sequences of $H$. pylori strains with the Basic Local Alignment Search Tool (http://blast.ncbi.nlm.nih.gov/Blast.cgi).

\section{Analysis of cagland cagN diversity by PCR sequencing}

For DNA sequencing of cagland cagN, PCR amplification was carried out in a final volume of $25 \mu \mathrm{l}$ using designed specific primers including 5'-CATTTGACTTACCTTGATTAC-3' (cag/F) and 5'TTTGAGCACTTGTTGGTTGG-3' (caglR), 5'-GAGCGACAAAACAACTATGC-3' (cagN-F) and 5'GATCCCTAGAACAAAGTAAGC-3' (cagN-R) yielding DNA fragments of about 1377 and 1192 bp in length, respectively. The PCR products were purified using the Silica Bead DNA Gel Extraction Kit (Thermo Scientific, Fermentas, USA) followed by sequencing on both strands using an automated sequencer (Macrogen, Seoul, Korea). DNA sequences were edited by Chromas Lite version 2.5.1 (Technelysium Pty Ltd, Australia) and BioEdit version 7.2.5 [30]. All of complete and partial cag/ and cagN nucleotide and amino acid sequences were aligned to the relevant sequences of $H$. pylori strain P12 (GenBank: $\mathrm{CP} 001217.1)$ as a reference sequence after in-frame translation. The single nucleotide variations and codon usage of the sequences were examined using BioEdit version 7.2.5.

\section{Phylogenetic analysis}

Phylogenetic trees were generated for Cagl and CagN nucleotide and amino acid sequences using Molecular Evolutionary Genetics Analysis version 7.0 (MEGA7) [31]. Evolutionary history was inferred by the Maximum Likelihood trees using Tamura 3-parameter model and Poisson correction method for nucleotide and amino acid sequences, respectively.

\section{Nucleotide sequence accession numbers}


The complete and partial nucleotide sequences of cagl and cagN genes from $\mathrm{H}$. pylori strains determined in this study were deposited in the NCBI GenBank database under the accession numbers MG573078MG573107 (cag) and MG559675-MG559720 (cagN).

\section{Statistical analysis}

The statistical associations between $H$. pylori virulence genotypes and different clinical status were determined by the Chi-square and Fisher's exact tests. A two-sided $P$ value of less than 0.05 was regarded statistically significant. The IBM SPSS Statistics for Windows version 21.0 (Armonk, NY: IBM Corp.) was used for all statistical analyses.

\section{Results}

\section{Demographic and clinical characteristics of patients}

The median age of the patients was 45.6 years (ranging from 14 to 75 years). Of the study cohort, $32.8 \%$ ( $n=23)$ was male and $67.1 \%(n=47)$ was female. According to the endoscopic and histopathology findings, 39 (55.7\%) patients were diagnosed with were non-ulcer dyspepsia (NUD), 23 (32.8\%) patients had peptic ulcer disease (PUD), 7 (10\%) patients had intestinal metaplasia (IM), and one (1.4\%) had gastric cancer. Three patients (4.3\%) suffered from gastritis and duodenitis simultaneously. Table 2 indicates the demographic characteristics and clinical status of the included subjects. In each of the 70 cases, H. pylori was isolated by culture and the isolates were approved by detection of the $\mathrm{g} / \mathrm{mM}$ and $16 \mathrm{~s}$ rRNA genes.

\section{Virulence genotypes and variants}

The molecular analysis revealed that the cagA, cagl, cagN, cagL, vacA s $1 \mathrm{~m} 1, \operatorname{vacA} \mathrm{s} 1 \mathrm{~m} 2$, and $\operatorname{vac} A \mathrm{~s} 2 \mathrm{~m} 2$ positive strains had a prevalence of, respectively, 84\% ( $n=59), 80 \%$ ( $n=56), 91.4 \%(n=64), 91.4 \%(n=64)$, $32.8 \%(n=23), 42.8 \%(n=30)$, and $24.4 \%(n=17)$ in our study, whereas babA2, dupA, and sabA were detected in, respectively, $97.1 \%(n=68), 84.3 \%(n=59)$, and $84.3 \%(n=59)$ of the isolates included in this investigation (Table 3). There was no statistically significant relationship between the H. pylori virulence genotypes and clinical status of the patients $(P>0.05)$. On the other hand, the results obtained are compatible with the clinical status of the patients. In present study, $100 \%(23 / 70)$ of the PUD and $94.9 \%$ (37/70) of the NUD strains were positive for babA2 gene by PCR. Furthermore, the prevalence of cagN and cag $L$ genes for PUD strains is attributed to $95.6 \%(22 / 70)$ and $91.3 \%(21 / 70)$, respectively. In the meantime, patients suffering from NUD showed the frequency of $89.7 \%(35 / 70)$ and $94.9 \%$ (37/70) for the same genes as PUD. When it comes to vacA allelic combinations, vacA s $1 \mathrm{~m} 2$ was found to be the most common allele among the strains recovered from the PUD patients $(52.2 \%)$, whereas $42.8 \%$ and $33.3 \%$ of allelic combinations were assigned to $v a c A s 1 \mathrm{~m} 1$ and $v a c A s 2 \mathrm{~m} 2$, within the IM and NUD strains, respectively.

\section{cag/variants in patients with different clinical status}


Out of 56 cag-positive H. pylori strains, the cag/gene of 30 strains were randomly selected and sequenced. The full-length cag/gene was successfully sequenced in $27 \mathrm{H}$. pylori strains. Moreover, the $\mathrm{cag} /$ gene was partially sequenced in three strains due to poor quality of sequence data or sequencing errors. According to our sequencing data, there was no insertion or deletion in the full-length cagl fragment from $27 \mathrm{H}$. pylori studied, and sequence alignments were therefore straight forward. In addition, we performed in-frame translation for cag/gene into amino acid sequences, and investigated rates and locations of Cagl variants. The distribution of synonymous and nonsynonymous polymorphisms in cagl of $H$. pylori strains are represented in Figure 1 and Table 4. The most variable codon usage was observed at residues 20 to 25,55 to $60,94,181$ to 199,213 to 221 , and 241 to 268 . The Cagl E22, E221, and V268 amino acid variants occurred at higher rate in $H$. pylori isolates from NUD patients compared to that isolated from PUD individuals, however, this difference was not statistically significant. Moreover, Cagl variants A23, S57, and S94 were found to occur at non-significantly higher rates in H. pylori isolates from individuals with PUD compared to NUD patients. As we expected, the SKVIVK hexapeptide motif (376381) located at the C-terminal of Cagl was completely conserved among the cag/ sequenced $H$. pylori strains.

\section{cagNvariants in patients with different clinical status}

Regarding cagN sequence analysis, 46 strains were randomly sent for direct DNA sequencing from 64 cagN-positive H. pylori strains. The complete cagN gene was successfully sequenced in $43 \mathrm{H}$. pylori strains. Furthermore, the cagN gene fragments of three strains were partially sequenced as the same reasons for the cag/gene. The cagN sequencing findings showed a high level of variability in CagN nucleotide and protein sequences. The most variable codon usage was observed at residues 53 to 63 , socalled as CagN hypervariable motif (CagNHM), which includes many missense mutations and it is postulated to contain GDEEITEEEKK in the P12 reference strain. Moreover, a conserved hypothetical hexapeptide repeat (EAKDEN/K) was inserted in residues 278-283 among six H. pylori strains. Interestingly, this motif was repeated two times in a row in one of these clinical strains (EAKDENEAKDEN). The other insertion sequences were detected between residues 224-225 and 234-235 for VK and $\mathrm{KN}$ amino acids in one of the strains. The sequencing data analysis revealed that these insertion sequences in cagN gene caused no frameshift mutations as compared to the P12 reference strain. Figure 2 and Table 5 showed the distribution of synonymous and nonsynonymous polymorphisms of CagN among 43 H. pylori strains in this study.

\section{Phylogenetic analysis of H. pylori Cagl and CagN}

The phylogenetic trees of $\mathrm{cag} /$ nucleotide and amino acid sequences from $\mathrm{H}$. pylori isolates are illustrated in Figures 3 and 4, respectively. Generally, no characteristic clusters were observed between DNA and amino acid sequences of $\mathrm{Cagl}$ and different clinical status. Furthermore, on the basis of the CagN nucleotide and amino acid sequences, a phylogenetic tree was reconstructed by using the Maximum Likelihood method, which are illustrated in Figures 5 and 6, respectively. Similar to Cagl sequences, the CagN phylogenetic analysis indicated no characteristic clusters with regard to the clinical status. 


\section{Discussion}

Virulent H. pylori strains harbor the cagPAI ( $\left.\mathrm{cag}^{+}\right)$encoding a type IV secretion apparatus, which has been shown to inject CagA and possibly also other virulence effectors into infected gastric epithelial cells [32]. It has been well documented that $\mathrm{cag}^{+} H$. pylori strains augment the risk for severe gastritis, peptic ulceration, atrophic gastritis, dysplasia, and gastric adenocarcinoma compared to strains that lack the cagPAI ( $\left.\mathrm{cag}^{-}\right)$[33-35]. Previously, it has been described that Cagl forms a functional protein complex at the bacterial cell surface by interacting with CagL, which is another important Cag secretion apparatus component. Accordingly, some evidence suggested that Cagl can interact with CagL protein and let to bind to integrin receptors on the target cell surface $[9,18]$. Cagl and CagL proteins contain N-terminal signal peptide, and therefore they can be supposed to be transported to the periplasm, however, the two proteins are not distributed equally on the bacterial cell surface [36]. Regarding different views on Cagl, Kumar et al. [37] found that Cagl does not participate in CagA translocation from cytoplasm to bacterial cell surface. On the other hand, it has been discovered that mutation in cagN did not interrupt CagA delivery or IL-8 secretion and the CagN-deficient $H$. pylori strains could cause an infection similar to wildtype $H$. pylori strains. Some experiments also have indicated that CagN is not conclusively required for $H$. pylori T4SS function [17]. In another study conducted by Kutter et al., CagN was established to interact with two other cagPAl proteins, including CagV and CagY [36]. Thus, the biological function of CagN is yet to be investigated. In the current study, the attempts were made to detect possible variants of Cagl and CagN, as uncharacterized cagPAl-encoded factors, on both nucleotide and amino acid sequence levels among $H$. pylori isolates in Iran. We also investigated the distribution and variations in $H$. pylori virulence factors. Our findings revealed that $80 \%$ of $H$. pylori isolates harbored cag/gene, whilst $91.4 \%$ of strains had cagN gene. To the best of our knowledge, the cagl and cagN variants in $\mathrm{H}$. pylori isolates in the subset of patients with different gastroduodenal diseases are not available in the literature. Based on our molecular findings, Cagl E22, E221, and V268 amino acid polymorphisms occurred at higher rate in $H$. pylori isolates from NUD individuals compared to that isolated from PUD patients, however, this difference was not statistically significant. On the other hand, Cagl amino acid changes A23, S57, and S94 were detected at non-significantly higher rates in H. pylori isolates from PUD patients compared to NUD subjects.

Despite the fact that Olbermann et al. found that cagN and cagM were demonstrated to be conserved in the cagPAl throughout all $\mathrm{cag}^{+}$H. pylori strains that have been sequenced so far [12], a high level of variability in CagN nucleotide and protein sequences was observed in present study. In the meantime, the most variable region in CagN amino acid sequence was found at residues 53 to 63, which includes many missense mutations and it is postulated to contain GDEEITEEEKK in the P12 reference strain. Our findings revealed that there was no significant correlation between clinical outcomes and $\mathrm{cag} /$ and $\mathrm{cagN}$ variants at both nucleotide and amino acid levels $(P>0.05)$, which is in consistent with previous study reported by Ogawa et al. [26]. Pham et al., stated that C-terminal motif (SKVIVK) in Cagl is essential for T4SS function, and thus is completely conserved among H. pylori strains. Remarkably, the C-terminal motif of Cagl is reported to be similar to the C-terminal motifs of CagL SK(I/V)IVK and CagH TKIIVK, 
representing the possibility that the amino acid sequences essentially act as binding motifs for a common interaction partner of all three proteins [18]. In agreement with above mentioned study, our findings also confirmed that the Cagl C-terminal motif was completely conserved among all H. pylori isolates. Ogawa et al. discovered complete RGD motifs in CagL sequences were observed from all isolates, which possibly imply the importance of the RGD motif for CagL function [26]. A recent investigation on this topic was performed by Yadegar et al. in Iran, in which almost $97 \%$ of $H$. pylori clinical strains contained cagL gene [29]. Furthermore, their findings highlighted the importance of a common CagL hypervariable motif (CagLHM) such as NEIGQ along with multiple C-type EPIYA repeats, which was linked to PUD, GE, and GC with more severity compared to NUD. In fact, it is believed that the over mentioned CagLHM motif played a key role in the pathogenesis of H. pylori strains. Besides, sequencing analysis of the present study also showed that a conserved hypothetical hexapeptide repeat (EAKDEN/K) was detected in residues $278-283$ in CagN among $13.9 \%$ of $H$. pylori isolates. Although Bats et al. [38] implied that the mutations and truncations in CagN sequence was irrelevant to folding properties or the overall shape of $\mathrm{CagN}$, further studies are required to assess the impact of this hexapeptide motif on CagN protein structure and its role in H. pylori T4SS activity. Despite the alterations in various cag sequences, it is noticeable that all patients had high prevalence of cagPAl genes including $c a g l, \operatorname{cagN}, \operatorname{cag} A$ and $\operatorname{cag} L$ that indicates more potential role of these genes in disease outcome.

In the preset study, we also investigated the presence of various $H$. pylori virulence genotypes. In accordance with our previous study in Iranian populations, we detected a high prevalence of vacAs1 (77.1\%) and vacA m2 (65.7\%) allelic genotypes [39]. The vacA s1 allele has been reported to be associated with more severe atrophic gastritis in peptic ulcer patients [40,41]. In our study, the vacA s 1 genotype was found to be more prevalent among PUD patients, however, there was no significant association between the presence of other virulence genes and clinical disease outcomes. The mosaic combination of s-and m-region allelic genotypes also has been established to be associated with the pathogenicity of $H$. pylori $[42,43]$. Accordingly, type $s 1 \mathrm{~m} 1 \mathrm{H}$. pylori strains express large amounts of VacA toxin and are strongly associated with a higher level of inflammation and mucosal ulceration, while vacA s1m2-harboring strains produce moderate amount of toxin and vacA s2m2 strains are virtually non-toxic and rarely associated to clinical outcome [44]. A majority of $H$. pylori strains in the current study contained vacA s1m2 genotype and this was mainly observed in NUD patients. On the contrary, allelic combination $\mathrm{s} 1 \mathrm{~m} 1$ or $\mathrm{s} 2 \mathrm{~m} 2$ genotypes were detected among the majority of clinical isolates of $\mathrm{H}$. pylori in other parts of the world, and the hypervirulent vacA $\mathrm{s} 1 \mathrm{~m} 1$ genotype was commonly associated with PUD patients [45]. Hence, it can be inferred that correlation between H. pylori genotyping and clinical outcome of the patients vary in different geographical regions.

\section{Conclusion}

In summary, a large body of evidence indicates that certain cagPAI components are correlated with the risk of gastric carcinogenesis. Here, we investigated the diversity of Cagl and CagN sequences in clinical H. pylori isolates from Iranian patients with different clinical status. We detected several putative variants of Cagl and CagN sequences in H. pylori isolates, however, there was no significant relevance between 
these variants and clinical phenotypes. Our findings also demonstrated that the C-terminal SKVIVK motif within the Cagl protein is conserved among all tested $H$. pylori strains. Meanwhile, the repeating motif EAKDEN was a typical attribute identified in C-terminal sequence of CagN protein among some of the $H$. pylori strains, however its potential impact on T4SS activity and translocation of effectors requires further investigations. Despite the present study has successfully demonstrated the genetic diversity of cag/and cagN genes, it has certain limitations in terms of insufficient sample size. Accordingly, the possible effects of Cagl and CagN variants on the T4SS activity as well as their possible interactions with other cagPAl components in a large number of $H$. pylori isolates needs to be explored. Also, the probable relevance of overmentioned variants with different clinical outcomes should not be ignored.

\section{Declarations}

\section{Acknowledgments}

The authors wish to thank the laboratory staff of Foodborne and Waterborne Diseases Research Center, Research Institute for Gastroenterology and Liver Diseases, Shahid Beheshti University of Medical Sciences, Tehran, Iran.

\section{Authors contribution}

YA and SK cultured the isolates and performed the PCR test. AY worked on concepts and designed the study. AY, NM and HH participated in data analysis and wrote the manuscript. NK, HAA and MRZ critically revised the manuscript. All authors approved the final version of the manuscript.

\section{Funding}

This study was supported financially by a grant (no. RIGLD 969) from Foodborne and Waterborne Diseases Research Center, Research Institute for Gastroenterology and Liver Diseases, Shahid Beheshti University of Medical Sciences, Tehran, Iran.

\section{Availability of data and materials}

The available data used and/or analyzed during the current study are all included in the manuscript.

\section{Ethical approval}

This work deals with clinical bacterial strains isolated from human gastric biopsies. No tissue material or other biological material was stored from the patients, only subcultured bacterial isolates. Informed consent was obtained from all individual participants included in the study. All procedures performed were in accordance with the ethical standards retrieved from the Institutional Ethical Review Committee of Research Institute for Gastroenterology and Liver Diseases (RIGLD) at Shahid Beheshti University of Medical Sciences (Project No. IR.SBMU.RIGLD.REC.1398.023).

\section{Consent for publication}


Not applicable.

\section{Competing interests}

The authors declare that they have no conflicts of interest.

\section{References}

1. Amieva MR, El-Omar EM. Host-bacterial interactions in Helicobacter pylori infection. Gastroenterol. 2008;134(1):306-23.

2. Naumann M, Sokolova O, Tegtmeyer N, Backert S. Helicobacter pylori: A paradigm pathogen for subverting host cell signal transmission. Trends Microbiol. 2017.

3. Cover TL, Blaser MJ. Helicobacter pylori in health and disease. Gastroenterol. 2009;136(6):1863-73.

4. Eusebi LH, Zagari RM, Bazzoli F. Epidemiology of Helicobacter pylori infection. Helicobacter. 2014;19(Suppl 1):1-5.

5. Malfertheiner P, Link A, Selgrad M. Helicobacter pylori: perspectives and time trends. Nat Rev Gastroenterol Hepatol. 2014;11(10):628-38.

6. Polk DB, Peek RM Jr. Helicobacter pylori: gastric cancer and beyond. Nature reviews Cancer. 2010;10(6):403.

7. Backert S, Neddermann M, Maubach G, Naumann M. Pathogenesis of Helicobacter pylori infection. Helicobacter. 2016;21(Suppl 1):19-25.

8. Hatakeyama M. Helicobacter pylori CagA and gastric cancer: a paradigm for hit-and-run carcinogenesis. Cell Host Microbe. 2014;15(3):306-16.

9. Kwok T, Zabler D, Urman S, Rohde M, Hartig R, Wessler S, Misselwitz R, Berger J, Sewald N, Konig W, et al. Helicobacter exploits integrin for type IV secretion and kinase activation. Nature. 2007;449(7164):862-6.

10. Backert S, Tegtmeyer N, Fischer W. Composition, structure and function of the Helicobacter pylori cag pathogenicity island encoded type IV secretion system. Future Microbiol. 2015;10(6):955-65.

11. Tegtmeyer N, Wessler S, Backert S. Role of the cag-pathogenicity island encoded type IV secretion system in Helicobacter pylori pathogenesis. FEBS J. 2011;278(8):1190-202.

12. Olbermann $P$, Josenhans $C$, Moodley $Y$, Uhr M, Stamer $C$, Vauterin $M$, Suerbaum S, Achtman $M$, Linz B. A Global Overview of the Genetic and Functional Diversity in the Helicobacter pyloricag Pathogenicity Island. PLOS Genetic. 2010;6(8):e1001069.

13. Cendron L, Zanotti G. Structural and functional aspects of unique type IV secretory components in the Helicobacter pylori cag-pathogenicity island. FEBS J. 2011;278(8):1223-31.

14. Merino E, Flores-Encarnacion $M$, Aguilar-Gutierrez GR. Functional interaction and structural characteristics of unique components of Helicobacter pylori T4SS. FEBS J. 2017;284(21):3540-9. 
15. Bourzac KM, Satkamp LA, Guillemin K. The Helicobacter pylori cag pathogenicity island protein CagN is a bacterial membrane-associated protein that is processed at its $\mathrm{C}$ terminus. Infect Immun. 2006;74(5):2537-43.

16. Ta LH, Hansen LM, Sause WE, Shiva O, Millstein A, Ottemann KM, Castillo AR, Solnick JV. Conserved transcriptional unit organization of the cag pathogenicity island among Helicobacter pylori strains. Front Cell Infect Microbiol. 2012;2:46.

17. Fischer W, Püls J, Buhrdorf R, Gebert B, Odenbreit S, Haas R. Systematic mutagenesis of the Helicobacter pylori cag pathogenicity island: essential genes for CagA translocation in host cells and induction of interleukin-8. Mol Microbiol. 2001;42(5):1337-48.

18. Pham KT, Weiss E, Soto LFJ, Breithaupt U, Haas R, Fischer W. Cagl is an essential component of the Helicobacter pylori Cag type IV secretion system and forms a complex with CagL. PloS one. 2012;7(4):e35341.

19. Sharma CM, Hoffmann S, Darfeuille F, Reignier J, Findeiß S, Sittka A, Chabas S, Reiche K, Hackermüller J, Reinhardt R. The primary transcriptome of the major human pathogen Helicobacter pylori. Nature. 2010;464(7286):250-5.

20. Li SD, Kersulyte D, Lindley IJ, Neelam B, Berg DE, Crabtree JE. Multiple Genes in the Left Half of the cagPathogenicity Island of Helicobacter pylori Are Required for Tyrosine Kinase-Dependent Transcription of Interleukin-8 in Gastric Epithelial Cells. Infect Immun. 1999;67(8):3893-9.

21. Selbach M, Moese S, Meyer TF, Backert S. Functional analysis of the Helicobacter pylori cag pathogenicity island reveals both VirD4-CagA-dependent and VirD4-CagA-independent mechanisms. Infect Immun. 2002;70(2):665-71.

22. Jimenez-Soto LF, Kutter S, Sewald X, Ertl C, Weiss E, Kapp U, Rohde M, Pirch T, Jung K, Retta SF, et al. Helicobacter pylori type IV secretion apparatus exploits beta1 integrin in a novel RGD-independent manner. PLoS Pathog. 2009;5(12):e1000684.

23. Shaffer CL, Gaddy JA, Loh JT, Johnson EM, Hill S, Hennig EE, McClain MS, McDonald WH, Cover TL. Helicobacter pylori exploits a unique repertoire of type IV secretion system components for pilus assembly at the bacteria-host cell interface. PLoS Pathog. 2011;7(9):e1002237.

24. Gorrell RJ, Zwickel N, Reynolds J, Bulach D, Kwok T. Helicobacter pylori CagL hypervariable motif: a global analysis of geographical diversity and association with gastric cancer. J Infect Dis. 2016;213(12):1927-31.

25. Linz B, Windsor HM, Gajewski JP, Hake CM, Drautz DI, Schuster SC, Marshall BJ. Helicobacter pylori genomic microevolution during naturally occurring transmission between adults. PloS one. 2013;8(12):e82187.

26. Ogawa H, Iwamoto A, Tanahashi T, Okada R, Yamamoto K, Nishiumi S, Yoshida M, Azuma T. Genetic variants of Helicobacter pylori type IV secretion system components CagL and Cagl and their association with clinical outcomes. Gut Pathog. 2017;9(1):21.

27. Rizzato C, Torres J, Plummer M, Muñoz N, Franceschi S, Camorlinga-Ponce M, Fuentes-Pananá EM, Canzian F, Kato I. Variations in Helicobacter pylori cytotoxin-associated genes and their influence in 
progression to gastric cancer: implications for prevention. PLoS One. 2012;7(1):e29605.

28. Yadegar A, Alebouyeh M, Lawson AJ, Mirzaei T, Mojarad EN, Zali MR. Differentiation of non-pylori Helicobacter species based on PCR-restriction fragment length polymorphism of the 23S rRNA gene. World J Microbiol Biotechnol. 2014;30(6):1909-17.

29. Yadegar A, Mohabati Mobarez A, Zali MR. Genetic diversity and amino acid sequence polymorphism in Helicobacter pylori CagL hypervariable motif and its association with virulence markers and gastroduodenal diseases. Cancer Med. 2019;8(4):1619-32.

30. Hall TA. BioEdit: a user-friendly biological sequence alignment editor. and analysis program for Windows 95/98/NT. In: Nucleic Acids Symp Ser. 1999: [London]: Information Retrieval Ltd., c1979c2000.; 1999: 95-98.

31. Kumar S, Stecher G, Tamura K. MEGA7. molecular evolutionary genetics analysis version 7.0 for bigger datasets. Mol Biol Evol. 2016;33(7):1870-4.

32. Noto JM, Peek RM. The Helicobacter pylori cag pathogenicity island. In: Helicobacter Species. edn.: Springer; 2012: 41-50.

33. Crabtree J, Taylor J, Heatley R, Shallcross T, Rathbone B, Wyatt J, Tompkins D. Mucosal IgA recognition of Helicobacter pylori 120 kDa protein, peptic ulceration, and gastric pathology. Lancet. 1991;338(8763):332-5.

34. Crabtree J, Wyatt J, Sobala G, Miller G, Tompkins D, Primrose J, Morgan A. Systemic and mucosal humoral responses to Helicobacter pylori in gastric cancer. Gut. 1993;34(10):1339-43.

35. Torres J, Pérez-Pérez GI, Leal-Herrera Y, MUNoz O. Infection with CagA + Helicobacter pylori strains as a possible predictor of risk in the development of gastric adenocarcinoma in Mexico. Int $\mathrm{J}$ cancer. 1998;78(3):298-300.

36. Kutter S, Buhrdorf R, Haas J, Schneider-Brachert W, Haas R, Fischer W. Protein Subassemblies of the Helicobacter pylori Cag Type IV Secretion System Revealed by Localization and Interaction Studies. J Biotechnol. 2008;190(6):2161-71.

37. Kumar N, Shariq M, Kumari R, Tyagi RK, Mukhopadhyay G. Cag type IV secretion system: Cagl independent bacterial surface localization of CagA. PLoS One. 2013;8(9):e74620.

38. Bats SH, Bergé C, Coombs N, Terradot L, Josenhans C. Biochemical characterization of the Helicobacter pylori Cag Type 4 Secretion System protein CagN and its interaction partner CagM. Int J Med Microbiol. 2018;308(4):425-37.

39. Yadegar A, Mobarez AM, Alebouyeh M, Mirzaei T, Kwok T, Zali MR. Clinical relevance of cagL gene and virulence genotypes with disease outcomes in a Helicobacter pylori infected population from Iran. World J Microbiol Biotechnol. 2014;30(9):2481-90.

40. Chiurillo MA, Moran Y, Cañas M, Valderrama E, Granda N, Sayegh M, Ramírez JL. Genotyping of Helicobacter pylori virulence-associated genes shows high diversity of strains infecting patients in western Venezuela. Int J Infect Dis. 2013;17(9):e750-6.

41. van Doorn L-J, Schneeberger P, Nouhan N, Plaisier A, Quint W, De Boer W. Importance of Helicobacter pylori cagA and vacAstatus for the efficacy of antibiotic treatment. Gut. 2000;46(3):321-6. 
42. Chauhan N, Tay ACY, Marshall BJ, Jain U. Helicobacter pylori VacA, a distinct toxin exerts diverse functionalities in numerous cells: An overview. Helicobacter. 2019;24(1):e12544.

43. Palframan SL, Kwok T, Gabriel K. Vacuolating cytotoxin A (VacA), a key toxin for Helicobacter pylori pathogenesis. Front cell Infect Microbiol. 2012;2:92.

44. Atherton JC, Cao P, Peek RM, Tummuru MK, Blaser MJ, Cover TL. Mosaicism in vacuolating cytotoxin alleles of Helicobacter pylori association of specific vacA types with cytotoxin production and peptic ulceration. J Biol Chem. 1995;270(30):17771-7.

45. Miernyk K, Morris J, Bruden D, McMahon B, Hurlburt D, Sacco F, Parkinson A, Hennessy T, Bruce M. Characterization of Helicobacter pylori cagA and vacA genotypes among Alaskans and their correlation with clinical disease. J Clin Microbiol. 2011;49(9):3114-21.

46. Farzi N, Yadegar A, Sadeghi A, Asadzadeh Aghdaei H, Marian Smith S, Raymond J, Suzuki H, Zali MR. High prevalence of antibiotic resistance in Iranian Helicobacter pylori Isolates: importance of functional and mutational analysis of resistance genes and virulence genotyping. $J$ Clin Med. 2019;8(11):2004.

\section{Tables}

Table 1. Oligonucleotide sequences used for amplification of the $H$. pylori virulence genes of interest.

\begin{tabular}{|c|c|c|c|c|c|}
\hline Target gene & Primer designation & Oligonucleotide sequence (5口-3ロ) & Annealingtemperature $\left({ }^{\circ} \mathrm{C}\right)$ & PCR product (bp) & Reference \\
\hline \multirow[t]{2}{*}{ 16S rRNA } & C97-20 & GGCTATGACGGGTATCCGGC & 58 & 764 & {$[39]$} \\
\hline & Н3А-20 & GCCGTGCAGCACCTGTTTTC & & & \\
\hline \multirow[t]{2}{*}{$\operatorname{glm} M$} & GlmM2-F & GGATAAGCTTTTAGGGGTGTTAGGGG & 56 & 296 & [39] \\
\hline & GlmM1-R & GCTTACTTTCTAACACTAACGCGC & & & \\
\hline \multirow[t]{2}{*}{$\operatorname{cagL}$} & cagL-B4 & GCAGAATTCATAACAAGCGGCTTAAAG & 60 & 695 & [39] \\
\hline & cagL-B5 & ATTAGAATTCATAGCCTATCGTCTCAG & & & \\
\hline \multirow[t]{2}{*}{$\operatorname{cag} A$} & 93089 & AATACACCAACGCCTCCAAG & 57 & 400 & [39] \\
\hline & 93261 & TTGTTGCCGCTTTTGCTCTC & & & \\
\hline \multirow[t]{2}{*}{$\operatorname{vac} A \mathrm{~s} 1 / \mathrm{s} 2$} & VA1-F & ATGGAAATACAACAAACACAC & 57 & $259 / 286$ & {$[39]$} \\
\hline & VA1-R & CTGCTTGAATGCGCCAAAC & & & \\
\hline \multirow[t]{2}{*}{ vacA $\mathrm{m} 1 / \mathrm{m} 2$} & VAG-F & CAATCTGTCCAATCAAGCGAG & 57 & $570 / 645$ & [39] \\
\hline & VAG-R & GCGTCAAAATAATTCCAAGG & & & \\
\hline \multirow[t]{2}{*}{$b a b A 2$} & bab7-F & CCAAACGAAACAAAAAGCGT & 52 & 271 & {$[46]$} \\
\hline & bab7-R & GCTTGTGTAAAAGCCGTCGT & & & \\
\hline \multirow[t]{2}{*}{$s a b A$} & F1-HP726-jhp663 & TTTTTGTCAGCTACGCGTTC & 56 & 487 & {$[46]$} \\
\hline & R1-HP725-jhp662 & ACCGAAGTGATAACGGCTTG & & & \\
\hline \multirow[t]{2}{*}{ dupA } & DupA-F & ATTCACGCCTAAGACCTCA & 55 & 581 & {$[46]$} \\
\hline & DupA-R & CTGAGAAGCCTTATTATCTTGTTGG & & & \\
\hline
\end{tabular}

'able 2. Demographic data and clinical characteristics of patients colonized with $H$. pylori strains ( $n=70$ ) in this study. 


\begin{tabular}{|c|c|c|c|c|c|c|}
\hline No. & Strains & Clinical status & Gender & Age (years) & $\operatorname{cagI}$ GenBank no. ${ }^{a}$ & $\operatorname{cagN}$ GenBank no. \\
\hline 1 & HC3 & PUD & Male & 46 & Negative $^{b}$ & NA \\
\hline 2 & OC4 & PUD & Female & 58 & MG573078 & MG559675 \\
\hline 3 & ос30 & NUD & Male & 56 & MG573079 & MG559676 \\
\hline 4 & HC114 & PUD & Female & 49 & Negative & NA \\
\hline 5 & OC149 & NUD & Female & 31 & MG573080 & NA \\
\hline 6 & HC168 & PUD & Male & 49 & $\mathrm{NA}^{\mathrm{c}}$ & NA \\
\hline 7 & HC175 & NUD & Female & 27 & Negative & NA \\
\hline 8 & OC175 & NUD & Female & 30 & MG573081 & MG559677 \\
\hline 9 & OC179 & GC & Female & 63 & NA & MG559678 \\
\hline 10 & OC180 & $\mathrm{IM}$ & Female & 39 & Negative & NA \\
\hline 11 & OC217 & NUD & Female & 42 & Negative & Negative \\
\hline 12 & OC235 & PUD & Female & 75 & NA & NA \\
\hline 13 & OC245 & IM & Male & 48 & NA & Negative \\
\hline 14 & OC 250 & PUD & Male & 57 & NA & NA \\
\hline 15 & OC485 & NUD & Male & 54 & NA & MG559679 \\
\hline 16 & OC494 & NUD & Female & 42 & MG573082 & MG559680 \\
\hline 17 & OC505 & NUD & Female & 39 & NA & NA \\
\hline 18 & OC557 & PUD & Female & 50 & Negative & Negative \\
\hline 19 & OC562 & NUD & Female & 43 & MG573083 & NA \\
\hline 20 & OC571 & NUD & Female & 49 & Negative & MG559681 \\
\hline 21 & OC573 & NUD & Female & 36 & MG573084 & MG559682 \\
\hline 22 & OC576 & NUD & Female & 42 & MG573085 & MG559683 \\
\hline 23 & OC606 & PUD & Male & 60 & NA & MG559684 \\
\hline 24 & OC639 & PUD & Male & 25 & Negative & MG559685 \\
\hline 25 & OC656 & PUD & Male & 41 & NA & MG559686 \\
\hline 26 & OC658 & NUD & Female & 33 & NA & MG559687 \\
\hline 27 & OC661 & NUD & Male & 33 & MG573086 & MG559688 \\
\hline 28 & OC688 & $\mathrm{IM}$ & Female & 42 & MG573087 & MG559689 \\
\hline 29 & OC722 & NUD & Female & 43 & MG573088 & MG559718 \\
\hline 30 & OC723 & NUD & Male & 47 & NA & MG559690 \\
\hline 31 & OC728 & NUD & Female & 23 & NA & MG559691 \\
\hline 32 & OC731 & NUD & Female & 24 & MG573089 & NA \\
\hline 33 & OC734 & NUD & Male & 50 & MG573090 & MG559692 \\
\hline 34 & OC743 & NUD & Male & 60 & Negative & MG559693 \\
\hline 35 & OC749 & NUD & Male & 70 & NA & MG559694 \\
\hline 36 & OC751 & NUD & Female & 44 & MG573091 & MG559695 \\
\hline 37 & OC770 & NUD & Female & 73 & MG573092 & MG559696 \\
\hline 38 & OC775 & PUD & Female & 39 & NA & MG559697 \\
\hline 39 & OC776 & NUD & Male & 34 & MG573093 & NA \\
\hline 40 & OC785 & NUD & Male & 60 & Negative & MG559719 \\
\hline 41 & OC790 & NUD & Male & 26 & NA & MG559720 \\
\hline 42 & OC793 & NUD & Female & 41 & MG573094 & MG559698 \\
\hline
\end{tabular}




\begin{tabular}{|c|c|c|c|c|c|c|}
\hline 43 & OC796 & PUD & Female & 51 & MG573095 & MG559699 \\
\hline 44 & OC797 & IM & Female & 28 & NA & NA \\
\hline 45 & OC803 & NUD & Male & 52 & NA & MG559700 \\
\hline 46 & OC805 & NUD & Female & 48 & MG573096 & MG559701 \\
\hline 47 & OC808 & NUD & Female & 65 & NA & MG559702 \\
\hline 48 & OC810 & NUD & Female & 53 & NA & $\mathrm{NA}$ \\
\hline 49 & OC814 & PUD & Female & 25 & NA & MG559703 \\
\hline 50 & OC815 & NUD & Female & 34 & MG573105 & Negative \\
\hline 51 & OC816 & NUD & Male & 14 & NA & MG559704 \\
\hline 52 & OC819 & PUD & Female & 32 & NA & MG559705 \\
\hline 53 & OC824 & PUD & Female & 43 & MG573097 & NA \\
\hline 54 & OC840 & IM & Male & 54 & NA & MG559706 \\
\hline 55 & OC846 & NUD & Female & 52 & MG573098 & MG559707 \\
\hline 56 & OC852 & IM & Male & 45 & NA & MG559708 \\
\hline 57 & OC854 & NUD & Female & 71 & MG573099 & Negative \\
\hline 58 & OC884 & NUD & Female & 60 & Negative & Negative \\
\hline 59 & OC897 & PUD & Female & 60 & Negative & MG559709 \\
\hline 60 & OC912 & PUD & Female & 64 & MG573100 & MG559710 \\
\hline 61 & OC913 & PUD & Male & 42 & MG573106 & $\mathrm{NA}$ \\
\hline 62 & OC937 & NUD & Female & 48 & MG573101 & MG559711 \\
\hline 63 & OC939 & PUD & Male & 54 & MG573102 & MG559712 \\
\hline 64 & OC975 & IM & Female & 31 & MG573107 & MG559713 \\
\hline 65 & OC978 & PUD & Female & 45 & MG573103 & MG559714 \\
\hline 66 & OC983 & PUD & Female & 55 & Negative & $\mathrm{NA}$ \\
\hline 67 & OC996 & PUD & Female & 52 & MG573104 & MG559715 \\
\hline 68 & OC1021 & PUD & Female & 50 & NA & MG559716 \\
\hline 69 & OC1028 & NUD & Female & 27 & Negative & MG559717 \\
\hline 70 & OC1031 & NUD & Female & 52 & NA & NA \\
\hline
\end{tabular}

;C, gastric cancer; IM, intestinal metaplasia; NUD, nonulcer dyspepsia; PUD, peptic ulcer disease; NA, not assigned.

The accession numbers are deposited in GenBank database for cagI and cagN gene sequences of the $H$. pylori strains in this tudy.

The cagI-negative or $\operatorname{cag} N$-negative $H$. pylori strains.

The cagI-positive or cagN-positive $H$. pylori strains that either were not sequenced or sequenced unsuccessfully.

'able 3. Distribution of virulence genotypes in relation to clinical status among $70 \mathrm{H}$. pylori strains. 


\begin{tabular}{lccccc}
\hline Virulence genotypes & \multicolumn{4}{c}{ Clinical status } & $\begin{array}{c}\text { Total } \\
(n=70)\end{array}$ \\
\cline { 2 - 5 } & NUD & PUD & IM & GC & $(n=1)$ \\
\hline cagI-positive & $32(82 \%)$ & $17(73.9 \%)$ & $6(85.7 \%)$ & $1(100 \%)$ & $56(80 \%)$ \\
cagI-negative & $7(18 \%)$ & $6(26 \%)$ & $1(14.3 \%)$ & $0(0 \%)$ & $14(20 \%)$ \\
cagN-positive & $35(89.7 \%)$ & $22(95.6 \%)$ & $6(85.7 \%)$ & $1(100 \%)$ & $64(91.4 \%)$ \\
cagN-negative & $4(10.3 \%)$ & $1(4.3 \%)$ & $1(14.3 \%)$ & $0(0 \%)$ & $6(8.6 \%)$ \\
cagA-positive & $33(84.6 \%)$ & $19(82.6 \%)$ & $6(85.7 \%)$ & $1(100 \%)$ & $59(84.3 \%)$ \\
cagA-negative & $6(15.4 \%)$ & $4(17.4 \%)$ & $1(14.3 \%)$ & $0(0 \%)$ & $11(15.7 \%)$ \\
cagL-positive & $37(94.9 \%)$ & $21(91.3 \%)$ & $5(71.4 \%)$ & $1(100 \%)$ & $64(91.4 \%)$ \\
cagL-negative & $2(5.1 \%)$ & $2(8.7 \%)$ & $2(28.6 \%)$ & $0(0 \%)$ & $6(8.6 \%)$ \\
vacA s1m1 & $12(30.8 \%)$ & $8(34.8 \%)$ & $3(42.8 \%)$ & $0(0 \%)$ & $23(32.8 \%)$ \\
vacA s1m2 & $14(35.9 \%)$ & $12(52.2 \%)$ & $3(42.8 \%)$ & $1(100 \%)$ & $30(42.8 \%)$ \\
vacA s2m2 & $13(33.3 \%)$ & $3(13 \%)$ & $1(14.3 \%)$ & $0(0 \%)$ & $17(24.3 \%)$ \\
babA2-positive & $37(94.9 \%)$ & $23(100 \%)$ & $7(100 \%)$ & $1(100 \%)$ & $68(97.1 \%)$ \\
babA2-negative & $2(5.1 \%)$ & $0(0 \%)$ & $0(0 \%)$ & $0(0 \%)$ & $2(2.9 \%)$ \\
sabA-positive & $32(82 \%)$ & $20(87 \%)$ & $6(85.7 \%)$ & $1(100 \%)$ & $59(84.3 \%)$ \\
sabA-negative & $7(18 \%)$ & $3(13 \%)$ & $1(14.3 \%)$ & $0(0 \%)$ & $11(15.7 \%)$ \\
dupA-positive & $32(82 \%)$ & $20(87 \%)$ & $6(85.7 \%)$ & $1(100 \%)$ & $59(84.3 \%)$ \\
dupA-negative & $7(18 \%)$ & $3(13 \%)$ & $1(14.3 \%)$ & $0(0 \%)$ & $11(15.7 \%)$ \\
\hline
\end{tabular}

¡C, gastric cancer; IM, intestinal metaplasia; NUD, nonulcer dyspepsia; PUD, peptic ulcer disease.

'able 4. The frequency of amino acid and nucleotide substitutions of CagI among clinical strains of $H$. pylori $(n=27)$ from patients with different linical status. 


\begin{tabular}{|c|c|c|c|c|}
\hline CagI polymorphic residues $^{a}$ & Amino acid diversity & NUD $(n=19)$ & PUD $(n=7)$ & $\operatorname{IM}(n=1)$ \\
\hline \multirow[t]{2}{*}{2} & $\mathrm{~K} / \mathrm{N}$ & $18: 1$ & $7: 0$ & 1:0 \\
\hline & & $\mathrm{AA}(\mathrm{A} / \mathrm{G}): \mathrm{AAT}$ & AAA & AAA \\
\hline \multirow[t]{2}{*}{3} & $\mathrm{C} / \mathrm{S} / \mathrm{F}$ & $17: 1: 1$ & $7: 0: 0$ & $1: 0: 0$ \\
\hline & & TGT:TCG:TTT & TGT & TGT \\
\hline \multirow[t]{2}{*}{6} & $\mathrm{~S} / \mathrm{D}$ & $18: 1$ & $7: 0$ & $1: 0$ \\
\hline & & AGC:GAC & AGC & AGC \\
\hline \multirow[t]{2}{*}{9} & $\mathrm{~S} / \mathrm{F}$ & $18: 1$ & $7: 0$ & $1: 0$ \\
\hline & & TCT:TTT & TCT & TCT \\
\hline \multirow[t]{2}{*}{12} & $\mathrm{~T} / \mathrm{I}$ & $18: 1$ & $7: 0$ & $1: 0$ \\
\hline & & ACT:ATT & $\mathrm{ACT}$ & $\mathrm{ACT}$ \\
\hline \multirow[t]{2}{*}{22} & $\mathrm{E} / \mathrm{G}$ & $18: 1$ & $4: 3$ & $1: 0$ \\
\hline & & GA(A/G):GGG & GAA:GGG & GAA \\
\hline \multirow[t]{2}{*}{23} & $\mathrm{~V} / \mathrm{A} / \mathrm{I}$ & $17: 1: 1$ & 3:3:1 & 1:0:0 \\
\hline & & GTA:GCA:ATA & GTA:GCA:ATA & GTA \\
\hline \multirow[t]{2}{*}{25} & $\mathrm{I} / \mathrm{M}$ & $17: 2$ & $6: 1$ & $1: 0$ \\
\hline & & ATA:ATG & ATA:ATG & ATA \\
\hline \multirow[t]{2}{*}{34} & $\mathrm{I} / \mathrm{N}$ & $18: 1$ & $7: 0$ & 1:0 \\
\hline & & ATT:AAT & ATT & $\mathrm{ATT}$ \\
\hline \multirow[t]{2}{*}{40} & $\mathrm{~A} / \mathrm{V}$ & $18: 1$ & $7: 0$ & $1: 0$ \\
\hline & & GCC:GTC & GCC & GCC \\
\hline \multirow[t]{2}{*}{44} & $\mathrm{~T} / \mathrm{A}$ & $18: 1$ & $7: 0$ & 1:0 \\
\hline & & ACC:GCC & ACC & ACC \\
\hline \multirow[t]{2}{*}{$51^{b}$} & $\mathrm{~A} / \mathrm{V}$ & $17: 2$ & $7: 0$ & 1:0 \\
\hline & & GCㅁ:GTC & GC $\underline{C}$ & GC므 \\
\hline \multirow[t]{2}{*}{57} & $\mathrm{~N} / \mathrm{S}$ & $10: 9$ & $2: 5$ & $0: 1$ \\
\hline & & AAT:AGT & AAT:AGT & AGT \\
\hline \multirow[t]{2}{*}{94} & $\mathrm{G} / \mathrm{S}$ & $9: 10$ & $1: 6$ & $0: 1$ \\
\hline & & GGC:AGC & GGC:AGC & AGC \\
\hline \multirow[t]{2}{*}{116} & $\mathrm{~A} / \mathrm{G}$ & $18: 1$ & $7: 0$ & $1: 0$ \\
\hline & & GCG:GGG & GCG & GCG \\
\hline \multirow[t]{2}{*}{162} & $\mathrm{~A} / \mathrm{T}$ & $18: 1$ & $7: 0$ & $1: 0$ \\
\hline & & GCT:ACT & GCT & GCT \\
\hline \multirow[t]{2}{*}{166} & $\mathrm{~A} / \mathrm{V}$ & 19:0 & $6: 1$ & $1: 0$ \\
\hline & & GCG & GCG:GTG & GCG \\
\hline \multirow[t]{2}{*}{182} & $\mathrm{E} / \mathrm{K}$ & $18: 1$ & 7:0 & $1: 0$ \\
\hline & & GAA:AAA & GAA & GAA \\
\hline \multirow[t]{2}{*}{187} & $\mathrm{~A} / \mathrm{T}$ & $18: 1$ & $7: 0$ & $1: 0$ \\
\hline & & GCT:ACC & GCT & GCT \\
\hline \multirow[t]{2}{*}{190} & $\mathrm{~S} / \mathrm{N}$ & 19:0 & $6: 1$ & $1: 0$ \\
\hline & & AGT & AGT:AAT & AGT \\
\hline 192 & $\mathrm{~S} / \mathrm{F}$ & $18: 1$ & $7: 0$ & $1: 0$ \\
\hline & & TCT:TTT & TCT & $\mathrm{TCT}$ \\
\hline 195 & $\mathrm{~A} / \mathrm{T}$ & $17: 2$ & $6: 1$ & $1: 0$ \\
\hline & & GCT:ACT & GCT:ACT & GCT \\
\hline 199 & $\mathrm{~A} / \mathrm{T}$ & $18: 1$ & $7: 0$ & 1:0 \\
\hline & & GCT:ACT & GCT & GCT \\
\hline 204 & G/S & $18: 1$ & $7: 0$ & $1: 0$ \\
\hline & & GGT:AGT & GGT & GGT \\
\hline 213 & $\mathrm{~K} / \mathrm{E}$ & $16: 3$ & $7: 0$ & 1:0 \\
\hline & & AAA:GAA & AAA & AAA \\
\hline 221 & $\mathrm{~T} / \mathrm{E}$ & $15: 4$ & $7: 0$ & $1: 0$ \\
\hline & & ACA:GAG & ACA & ACA \\
\hline
\end{tabular}




\begin{tabular}{|c|c|c|c|c|}
\hline \multirow[t]{2}{*}{243} & \multirow[t]{2}{*}{$\mathrm{A} / \mathrm{T}$} & $15: 4$ & $5: 2$ & $1: 0$ \\
\hline & & GCC:ACC & GCC:ACC & GCC \\
\hline \multirow[t]{2}{*}{246} & \multirow[t]{2}{*}{$\mathrm{A} / \mathrm{V}$} & 19:0 & $6: 1$ & $1: 0$ \\
\hline & & GCG & GCG:GTG & GCG \\
\hline \multirow[t]{2}{*}{254} & \multirow[t]{2}{*}{$\mathrm{S} / \mathrm{N}$} & $17: 2$ & $7: 0$ & $1: 0$ \\
\hline & & AGC:AAC & AGC & AGC \\
\hline \multirow[t]{2}{*}{257} & \multirow[t]{2}{*}{$\mathrm{A} / \mathrm{T}$} & $18: 1$ & $7: 0$ & $1: 0$ \\
\hline & & GCA:ACA & GCA & GCA \\
\hline \multirow[t]{2}{*}{262} & \multirow[t]{2}{*}{$\mathrm{I} / \mathrm{F}$} & 18:1 & $7: 0$ & $1: 0$ \\
\hline & & ATT:TTT & ATT & ATT \\
\hline \multirow[t]{2}{*}{263} & \multirow[t]{2}{*}{$\mathrm{E} / \mathrm{Q}$} & $18: 1$ & $7: 0$ & 1:0 \\
\hline & & GAA:CAA & GAA & GAA \\
\hline \multirow[t]{2}{*}{268} & \multirow[t]{2}{*}{$\mathrm{A} / \mathrm{V} / \mathrm{E}$} & 13:5:1 & $6: 1: 0$ & $0: 1: 0$ \\
\hline & & GCA:GTG:GAG & GCA:GTG & GCA:GTG \\
\hline \multirow[t]{2}{*}{305} & \multirow[t]{2}{*}{$\mathrm{D} / \mathrm{G} / \mathrm{N}$} & 18:1:0 & $5: 1: 1$ & $1: 0$ \\
\hline & & GAT:GGT & GAT:GGT:AAT & GAT \\
\hline \multirow[t]{2}{*}{319} & \multirow[t]{2}{*}{ G/E } & 18:1 & $5: 2$ & $1: 0$ \\
\hline & & GGA:GAA & GGA:GAA & GGA \\
\hline \multirow[t]{2}{*}{320} & \multirow[t]{2}{*}{$\mathrm{E} / \mathrm{Q}$} & $18: 1$ & $5: 2$ & $1: 0$ \\
\hline & & GAA:CAA & GAA:CAA & GAA \\
\hline \multirow[t]{2}{*}{351} & \multirow[t]{2}{*}{$\mathrm{L} / \mathrm{F}$} & 18:1 & $7: 0$ & $1: 0$ \\
\hline & & CTT:TTT & СTT & СТT \\
\hline \multirow[t]{2}{*}{353} & \multirow[t]{2}{*}{$\mathrm{K} / \mathrm{T}$} & $18: 1$ & $7: 0$ & $1: 0$ \\
\hline & & AAA:ACA & AAA & AAA \\
\hline \multirow[t]{2}{*}{368} & \multirow[t]{2}{*}{$\mathrm{T} / \mathrm{M} / \mathrm{K}$} & $17: 1: 1$ & $7: 0$ & 10:0 \\
\hline & & ACG:ATG:AAG & ACG & ACG \\
\hline \multirow[t]{2}{*}{375} & \multirow[t]{2}{*}{$\mathrm{S} / \mathrm{G}$} & 19:0 & $5: 2$ & $0: 1$ \\
\hline & & AGC & AGC:GGC & GGC \\
\hline
\end{tabular}

M, intestinal metaplasia; NUD, nonulcer dyspepsia; PUD, peptic ulcer disease.

Positions of amino acid residues correspond to the $H$. pylori $\mathrm{P} 12$ reference strain.

The underlined nucleotides denote that all of our H. pylori strains had C in the third-base position of this codon compared to

1. pylori $\mathrm{P} 12$ that had $\mathrm{T}$.

Table 5. The frequency of amino acid and nucleotide substitutions of CagN among clinical strains of $H$. pylori ( $(n=43)$ from patients with different clinical status. 


\begin{tabular}{|c|c|c|c|c|c|}
\hline CagN polymorphic residues ${ }^{a}$ & Amino acid diversity & NUD $(n=24)$ & PUD $(n=14)$ & $\mathrm{IM}(n=4)$ & $\mathrm{GC}(n=1)$ \\
\hline \multirow[t]{2}{*}{8} & $\mathrm{~L} / \mathrm{I}$ & $24: 0$ & $13: 1$ & $4: 0$ & $1: 0$ \\
\hline & & $(\mathrm{C} / \mathrm{T}) \mathrm{TA}$ & CTA:ATA & CTA & CTA \\
\hline \multirow[t]{2}{*}{15} & $\mathrm{~S} / \mathrm{F}$ & $22: 2$ & 14:0 & $4: 0$ & $1: 0$ \\
\hline & & TCT:TTT & TCT & TCT & TCT \\
\hline \multirow[t]{2}{*}{17} & $\mathrm{~V} / \mathrm{A} / \mathrm{I}$ & 20:3:1 & $12: 1: 1$ & $4: 0: 0$ & 1:0:0 \\
\hline & & GTT:GCT:ATT & GTT:GCT:ATT & GTT & GTT \\
\hline \multirow[t]{2}{*}{18} & $\mathrm{I} / \mathrm{V}$ & $13: 11$ & $7: 7$ & $2: 2$ & $1: 0$ \\
\hline & & ATT:GTT & ATT:GTT & ATT:GTT & ATT \\
\hline \multirow[t]{2}{*}{32} & $\mathrm{~S} / \mathrm{N}$ & $24: 0$ & $13: 1$ & $4: 0$ & $1: 0$ \\
\hline & & AGT & AGT:AAT & AGT & AGT \\
\hline \multirow[t]{2}{*}{33} & $\mathrm{E} / \mathrm{K}$ & $23: 1$ & 14:0 & $4: 0$ & $1: 0$ \\
\hline & & GAA:AAA & GAA & GAA & GAA \\
\hline \multirow[t]{2}{*}{36} & $\mathrm{E} / \mathrm{K}$ & $15: 9$ & $13: 1$ & $2: 2$ & $1: 0$ \\
\hline & & GAA:AAA & GAA:AAA & GAA:AAA & GAA \\
\hline \multirow[t]{2}{*}{$38^{b}$} & $\mathrm{~A} / \mathrm{V}$ & $0: 24$ & $0: 14$ & $0: 4$ & $0: 1$ \\
\hline & & GTE & GCG:GI $(\mathrm{G} / \mathrm{A})$ & GT & GTG \\
\hline \multirow[t]{2}{*}{39} & $\mathrm{~A} / \mathrm{V}$ & $24: 0$ & $13: 1$ & $4: 0$ & $1: 0$ \\
\hline & & GCT & GCT:GTT & GCT & GCT \\
\hline \multirow[t]{2}{*}{46} & $\mathrm{~K} / \mathrm{T}$ & $24: 0$ & 13:1 & $3: 1$ & $1: 0$ \\
\hline & & $\mathrm{AA}(\mathrm{A} / \mathrm{G})$ & AAA:ACA & AAA:ACA & AAA \\
\hline \multirow[t]{2}{*}{48} & $\mathrm{~L} / \mathrm{F}$ & 16:8 & 8:6 & 3:1 & $0: 1$ \\
\hline & & CTC:TTC & CTC:TTC & CTC:TTC & TTC \\
\hline \multirow[t]{2}{*}{49} & $\mathrm{H} / \mathrm{Y}$ & $17: 7$ & 10:4 & $3: 1$ & $0: 1$ \\
\hline & & CAT:TAT & CAT:TAT & CAT:TAT & TAT \\
\hline \multirow[t]{2}{*}{52} & $\mathrm{H} / \mathrm{R}$ & $24: 0$ & $13: 1$ & $4: 0$ & $1: 0$ \\
\hline & & CAT & CAT:CGT & CAT & CAT \\
\hline \multirow[t]{2}{*}{53} & $\mathrm{G} / \mathrm{D}$ & $0: 24$ & $0: 14$ & $0: 4$ & $0: 1$ \\
\hline & & GAC & GAC & GAC & GAC \\
\hline \multirow[t]{2}{*}{54} & $\mathrm{D} / \mathrm{N}$ & $23: 1$ & $14: 0$ & $4: 0$ & $1: 0$ \\
\hline & & GAC:AA(C/T) & GAC & GAC & GAC \\
\hline \multirow[t]{2}{*}{55} & $\mathrm{E} / \mathrm{K}$ & $17: 7$ & $11: 3$ & $4: 0$ & $1: 0$ \\
\hline & & GAA:AAA & GAA:AAA & GAA & GAA \\
\hline \multirow[t]{2}{*}{57} & $\mathrm{I} / \mathrm{V}$ & 8:16 & 4:10 & $2: 2$ & $1: 0$ \\
\hline & & ATT:GTT & ATT:GTT & ATT:GTT & ATT \\
\hline \multirow[t]{2}{*}{59} & $\mathrm{E} / \mathrm{K}$ & 7:17 & 1:13 & 1:3 & $1: 0$ \\
\hline & & GAA:AAA & GAA:AAA & GAA:AAA & GAA \\
\hline \multirow[t]{2}{*}{61} & $\mathrm{E} / \mathrm{K}$ & $21: 3$ & $14: 0$ & $4: 0$ & $1: 0$ \\
\hline & & GAA:AAA & GAA & GAA & GAA \\
\hline \multirow[t]{2}{*}{63} & $\mathrm{~K} / \mathrm{E}$ & 8:16 & $2: 12$ & $1: 3$ & $1: 0$ \\
\hline & & AAA:GAA & AAA:GAA & AAA:GAA & AAA \\
\hline 80 & $\mathrm{~A} / \mathrm{V}$ & 24:0 & $12: 2$ & $3: 1$ & 1:0 \\
\hline & & GCA & GCA:GT(G/A) & GCA:GT(G/A) & GCA \\
\hline 98 & $\mathrm{~V} / \mathrm{I}$ & $6: 18$ & $5: 9$ & $3: 1$ & $0: 1$ \\
\hline & & GTT:ATT & GTT:ATT & GTT:ATT & ATT \\
\hline 102 & $\mathrm{~A} / \mathrm{V}$ & $22: 2$ & $14: 0$ & 4:0 & $1: 0$ \\
\hline & & GCG:GTG & GCG & $\mathrm{GC}(\mathrm{G} / \mathrm{A})$ & GCG \\
\hline 103 & $\mathrm{~A} / \mathrm{T} / \mathrm{S}$ & 16:8:0 & $8: 5: 1$ & $3: 1: 0$ & $1: 0$ \\
\hline & & GCT:ACT & GCT:ACT:TCT & GCT:ACT & GCT \\
\hline 106 & $\mathrm{~K} / \mathrm{R}$ & $21: 3$ & $13: 1$ & 4:0 & $1: 0$ \\
\hline & & AAA:AGA & AAA:AGA & AAA & AAA \\
\hline 114 & $\mathrm{I} / \mathrm{T}$ & 21:3 & 8:6 & $4: 0$ & $1: 0$ \\
\hline & & ATT:ACT & ATT:ACT & ATT & ATT \\
\hline
\end{tabular}




\begin{tabular}{|c|c|c|c|c|c|}
\hline \multirow[t]{2}{*}{117} & $\mathrm{~T} / \mathrm{N} / \mathrm{H}$ & $3: 7: 14$ & $2: 3: 9$ & $0: 3: 1$ & $0: 1: 0$ \\
\hline & & ACC:AAC:CAC & ACC:AAC:CAC & $\mathrm{AAC}: \mathrm{CAC}$ & AAC \\
\hline \multirow[t]{2}{*}{118} & $\mathrm{P} / \mathrm{S}$ & $24: 0$ & $13: 1$ & $4: 0$ & $1: 0$ \\
\hline & & CCT & CCT:TCT & CCT & CCT \\
\hline \multirow[t]{2}{*}{121} & $\mathrm{D} / \mathrm{N}$ & $22: 2$ & $14: 0$ & $4: 0$ & $1: 0$ \\
\hline & & GAC:AAC & GAC & GAC & GAC \\
\hline \multirow[t]{2}{*}{125} & $\mathrm{~S} / \mathrm{G}$ & $21: 3$ & $12: 2$ & 4:0 & $1: 0$ \\
\hline & & AGC:GGC & AGC:GGC & AGC & AGC \\
\hline \multirow[t]{2}{*}{129} & $\mathrm{~A} / \mathrm{T}$ & $8: 16$ & $3: 11$ & $0: 4$ & $0: 1$ \\
\hline & & GCT:ACT & GCT:ACT & ACT & ACT \\
\hline \multirow[t]{2}{*}{134} & $\mathrm{~N} / \mathrm{H}$ & $22: 2$ & $14: 0$ & $4: 0$ & $1: 0$ \\
\hline & & AAT:CAT & AAT & AAT & AAT \\
\hline \multirow[t]{2}{*}{137} & $\mathrm{D} / \mathrm{G}$ & $23: 1$ & $14: 0$ & $4: 0$ & $1: 0$ \\
\hline & & GAT:GGA & GAT & GAT & GAT \\
\hline \multirow[t]{2}{*}{140} & $\mathrm{D} / \mathrm{N}$ & $22: 2$ & $12: 2$ & $4: 0$ & $1: 0$ \\
\hline & & GAT:AAT & GAT:AAT & GAT & GAT \\
\hline \multirow[t]{2}{*}{148} & $\mathrm{E} / \mathrm{G}$ & $11: 13$ & $8: 6$ & $2: 2$ & $1: 0$ \\
\hline & & GAA:GGA & GAA:GGA & GAA:GGA & GAA \\
\hline \multirow[t]{2}{*}{149} & $\mathrm{~A} / \mathrm{S}$ & $17: 7$ & $10: 4$ & $2: 2$ & $1: 0$ \\
\hline & & GCT:TCT & GCT:TCT & GCT:TCT & GCT \\
\hline \multirow[t]{2}{*}{154} & $\mathrm{~A} / \mathrm{T} / \mathrm{V}$ & $21: 2: 1$ & $10: 4: 0$ & $3: 1: 0$ & $0: 1: 0$ \\
\hline & & GCT:ACT:GTT & GCT:ACT & GCT:ACT & ACT \\
\hline \multirow[t]{2}{*}{155} & $\mathrm{~A} / \mathrm{T}$ & $24: 0$ & 13:1 & 4:0 & $1: 0$ \\
\hline & & GCT & GCT:ACT & GCT & GCT \\
\hline \multirow[t]{2}{*}{160} & $\mathrm{~N} / \mathrm{D}$ & $6: 18$ & $3: 11$ & $0: 4$ & $1: 0$ \\
\hline & & AAT:GAT & AAT:GAT & GAT & AAT \\
\hline \multirow[t]{2}{*}{161} & $\mathrm{E} / \mathrm{K}$ & $24: 0$ & $13: 1$ & $4: 0$ & $1: 0$ \\
\hline & & GAG & GAG:AAA & GAG & GAG \\
\hline \multirow[t]{2}{*}{170} & $\mathrm{I} / \mathrm{V}$ & $21: 3$ & $14: 0$ & $4: 0$ & $1: 0$ \\
\hline & & $\mathrm{AT}(\mathrm{T} / \mathrm{C}): \mathrm{GTT}$ & $\mathrm{AT}(\mathrm{T} / \mathrm{C})$ & ATT & ATT \\
\hline \multirow[t]{2}{*}{174} & $\mathrm{C} / \mathrm{G}$ & $23: 1$ & $14: 0$ & $4: 0$ & $1: 0$ \\
\hline & & TGT:GGT & TGT & TGT & TGT \\
\hline \multirow[t]{2}{*}{182} & $\mathrm{D} / \mathrm{N}$ & $24: 0$ & $13: 1$ & $3: 1$ & $1: 0$ \\
\hline & & GAT & GAT:AAT & GAT:AAT & GAT \\
\hline \multirow[t]{2}{*}{191} & $\mathrm{G} / \mathrm{D}$ & $24: 0$ & $12: 2$ & $3: 1$ & $1: 0$ \\
\hline & & $\mathrm{GG}(\mathrm{C} / \mathrm{T})$ & GGC:GAC & GGC:GAC & GGC \\
\hline \multirow[t]{2}{*}{194} & $\mathrm{D} / \mathrm{E}$ & $23: 1$ & $14: 0$ & $4: 0$ & $1: 0$ \\
\hline & & GAT:GAA & GAT & GAT & GAT \\
\hline \multirow[t]{2}{*}{199} & $\mathrm{~A} / \mathrm{T} / \mathrm{V}$ & $19: 5: 0$ & $8: 5: 1$ & $2: 2: 0$ & $1: 0: 0$ \\
\hline & & GCC:ACC & GCC:ACC:GTC & GCC:ACC & GCC \\
\hline 203 & $\mathrm{E} / \mathrm{K}$ & $23: 1$ & $14: 0$ & $3: 1$ & $1: 0$ \\
\hline & & GAA:AAA & $\mathrm{GA}(\mathrm{A} / \mathrm{G})$ & GAA:AAA & GAA \\
\hline 208 & $\mathrm{I} / \mathrm{V}$ & $23: 1$ & $14: 0$ & $4: 0$ & $1: 0$ \\
\hline & & ATA:GTA & ATA & ATA & ATA \\
\hline 221 & $\mathrm{~S} / \mathrm{N}$ & $22: 2$ & $14: 0$ & $4: 0$ & $1: 0$ \\
\hline & & AGT:AAT & AGT & AGT & AGT \\
\hline 224 & $\mathrm{~K} / \mathrm{R}$ & $23: 1$ & $14: 0$ & $4: 0$ & $1: 0$ \\
\hline & & AAA:AGA & AAA & AAA & AAA \\
\hline 225 & $\mathrm{~L} / \mathrm{F}$ & $23: 1$ & $14: 0$ & $4: 0$ & $1: 0$ \\
\hline & & $\mathrm{CT}(\mathrm{C} / \mathrm{T}): \mathrm{TTC}$ & CTC & СТC & СТС \\
\hline 226 & $\mathrm{~A} / \mathrm{V}$ & $23: 1$ & $14: 0$ & $4: 0$ & $1: 0$ \\
\hline & & GCT:GTT & GCT & GCT & GCT \\
\hline 227 & $\mathrm{~L} / \mathrm{F}$ & 24:0 & $12: 2$ & $3: 1$ & $0: 1$ \\
\hline
\end{tabular}




\begin{tabular}{|c|c|c|c|c|c|}
\hline & & $\mathrm{CT}(\mathrm{C} / \mathrm{T})$ & $\mathrm{CT}(\mathrm{C} / \mathrm{T}): \mathrm{TTT}$ & $\mathrm{CT}(\mathrm{C} / \mathrm{T}): \mathrm{TTT}$ & TTT \\
\hline \multirow[t]{2}{*}{228} & $\mathrm{~N} / \mathrm{H}$ & 24:0 & $13: 1$ & $4: 0$ & $1: 0$ \\
\hline & & AAT & AAT:CAT & AAT & AAT \\
\hline \multirow[t]{2}{*}{232} & $\mathrm{~N} / \mathrm{S}$ & $24: 0$ & $13: 1$ & $4: 0$ & $1: 0$ \\
\hline & & AAT & AAT:AGT & AAT & AAT \\
\hline \multirow[t]{2}{*}{233} & $\mathrm{R} / \mathrm{K}$ & $24: 0$ & $13: 1$ & 4:0 & $1: 0$ \\
\hline & & AGA & AGA:AAA & AGA & AGA \\
\hline \multirow[t]{2}{*}{241} & $\mathrm{~T} / \mathrm{A}$ & $2: 22$ & $1: 13$ & $0: 4$ & $0: 1$ \\
\hline & & ACT:GC (G/T) & ACT:GC (G/T) & ACT:GCT & GCT \\
\hline \multirow[t]{2}{*}{248} & $\mathrm{~K} / \mathrm{R}$ & $24: 0$ & $13: 1$ & 4:0 & $1: 0$ \\
\hline & & AAA & AAA:AGA & AAA & AAA \\
\hline \multirow[t]{2}{*}{259} & $\mathrm{~T} / \mathrm{I}$ & $23: 1$ & $14: 0$ & $4: 0$ & $1: 0$ \\
\hline & & ACT:ATT & ACT & $\mathrm{ACT}$ & $\mathrm{ACT}$ \\
\hline \multirow[t]{2}{*}{262} & $\mathrm{~A} / \mathrm{T}$ & $22: 2$ & $13: 1$ & 4:0 & $1: 0$ \\
\hline & & GCA:ACA & GCA:ACA & GCA & GCA \\
\hline \multirow[t]{2}{*}{263} & $\mathrm{~S} / \mathrm{G}$ & $24: 0$ & $14: 0$ & $3: 1$ & $1: 0$ \\
\hline & & $\mathrm{AG}(\mathrm{C} / \mathrm{T})$ & $\mathrm{AG}(\mathrm{C} / \mathrm{T})$ & $\mathrm{AG}(\mathrm{C} / \mathrm{T}): \mathrm{GGT}$ & AGT \\
\hline \multirow[t]{2}{*}{264} & $\mathrm{~K} / \mathrm{E}$ & $1: 23$ & $0: 14$ & $0: 4$ & $0: 1$ \\
\hline & & AAG:GA(G/A) & $\mathrm{GA}(\mathrm{G} / \mathrm{A})$ & $\mathrm{GA}(\mathrm{G} / \mathrm{A})$ & GAG \\
\hline \multirow[t]{2}{*}{267} & $\mathrm{~T} / \mathrm{A}$ & $9: 15$ & $3: 11$ & $2: 2$ & $0: 1$ \\
\hline & & ACT:GCT & ACT:GCT & ACT:GCT & GCT \\
\hline \multirow[t]{2}{*}{268} & $\mathrm{~T} / \mathrm{A}$ & $23: 1$ & $2: 12$ & $4: 0$ & $1: 0$ \\
\hline & & ACT:GCT & ACT:GCT & $\mathrm{ACT}$ & $\mathrm{ACT}$ \\
\hline \multirow[t]{2}{*}{273} & $\mathrm{~N} / \mathrm{S}$ & 23:1 & 14:0 & $4: 0$ & $1: 0$ \\
\hline & & $\mathrm{AA}(\mathrm{T} / \mathrm{C}): \mathrm{AGC}$ & $\mathrm{AA}(\mathrm{T} / \mathrm{C})$ & $\mathrm{AA}(\mathrm{T} / \mathrm{C})$ & AAT \\
\hline \multirow[t]{2}{*}{279} & $\mathrm{~T} / \mathrm{A} / \mathrm{V}$ & 16:7:1 & $9: 5: 0$ & $2: 2: 0$ & $0: 1: 0$ \\
\hline & & ACA:GC (A/G):GTG & ACA:GC(A/G) & ACA:GC (A/G) & GCA \\
\hline \multirow[t]{2}{*}{280} & $\mathrm{~F} / \mathrm{S}$ & $23: 1$ & $13: 1$ & $3: 1$ & 1:0 \\
\hline & & $\mathrm{TT}(\mathrm{C} / \mathrm{T}): \mathrm{TCC}$ & TTC:TCC & TTC:TCC & TTC \\
\hline \multirow[t]{2}{*}{284} & $\mathrm{R} / \mathrm{H}$ & $20: 4$ & $12: 2$ & 4:0 & $1: 0$ \\
\hline & & CGC:CAC & CGC:CAC & CGC & CGC \\
\hline \multirow[t]{2}{*}{285} & $\mathrm{~S} / \mathrm{F} / \mathrm{P}$ & $22: 2: 0$ & $14: 0: 0$ & $3: 0: 1$ & 1:0:0 \\
\hline & & TCT:TTT & TCT & TCT:CCT & $\mathrm{TCT}$ \\
\hline \multirow[t]{2}{*}{287} & $\mathrm{~S} / \mathrm{F}$ & 23:1 & 131 & 4:0 & $1: 0$ \\
\hline & & $\mathrm{TC}(\mathrm{T} / \mathrm{C}): \mathrm{TTT}$ & TCT:TT & $\mathrm{TC}(\mathrm{T} / \mathrm{C})$ & TCT \\
\hline \multirow[t]{2}{*}{288} & $\mathrm{E} / \mathrm{D}$ & $23: 1$ & $14: 0$ & $4: 0$ & $1: 0$ \\
\hline & & GA(A/G):GAC & $\mathrm{GA}(\mathrm{A} / \mathrm{G})$ & GAA & GAA \\
\hline \multirow[t]{2}{*}{302} & $\mathrm{~A} / \mathrm{V}$ & $23: 1$ & $14: 0$ & 4:0 & $1: 0$ \\
\hline & & GCT:GTT & GCT & GCT & GCT \\
\hline \multirow[t]{2}{*}{$304^{\mathrm{c}}$} & $\mathrm{E} / \mathrm{G}$ & $0: 24$ & $0: 14$ & $0: 4$ & $0: 1$ \\
\hline & & GAA:G $\underline{G A}$ & GAA:G $\underline{G A}$ & GAA:G $\underline{G A}$ & GAA:G $\underline{G A}$ \\
\hline
\end{tabular}

GC, gastric cancer; IM, intestinal metaplasia; NUD, nonulcer dyspepsia; PUD, peptic ulcer disease.

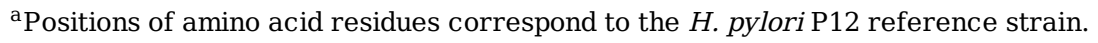

${ }^{\mathrm{b}}$ The underlined nucleotides denote that all of our $H$. pylori strains had $\mathrm{T}$ in the second-base position of this codon compared to $H$. pylori $\mathrm{P} 12$ that had C.

${ }^{\mathrm{C}}$ The underlined nucleotides denote that all of our $H$. pylori strains had G in the second-base position of this codon compared to $H$. pylori $\mathrm{P} 12$ that had A.

The inserted sequences are not indicated in the table. 


\section{Figures}
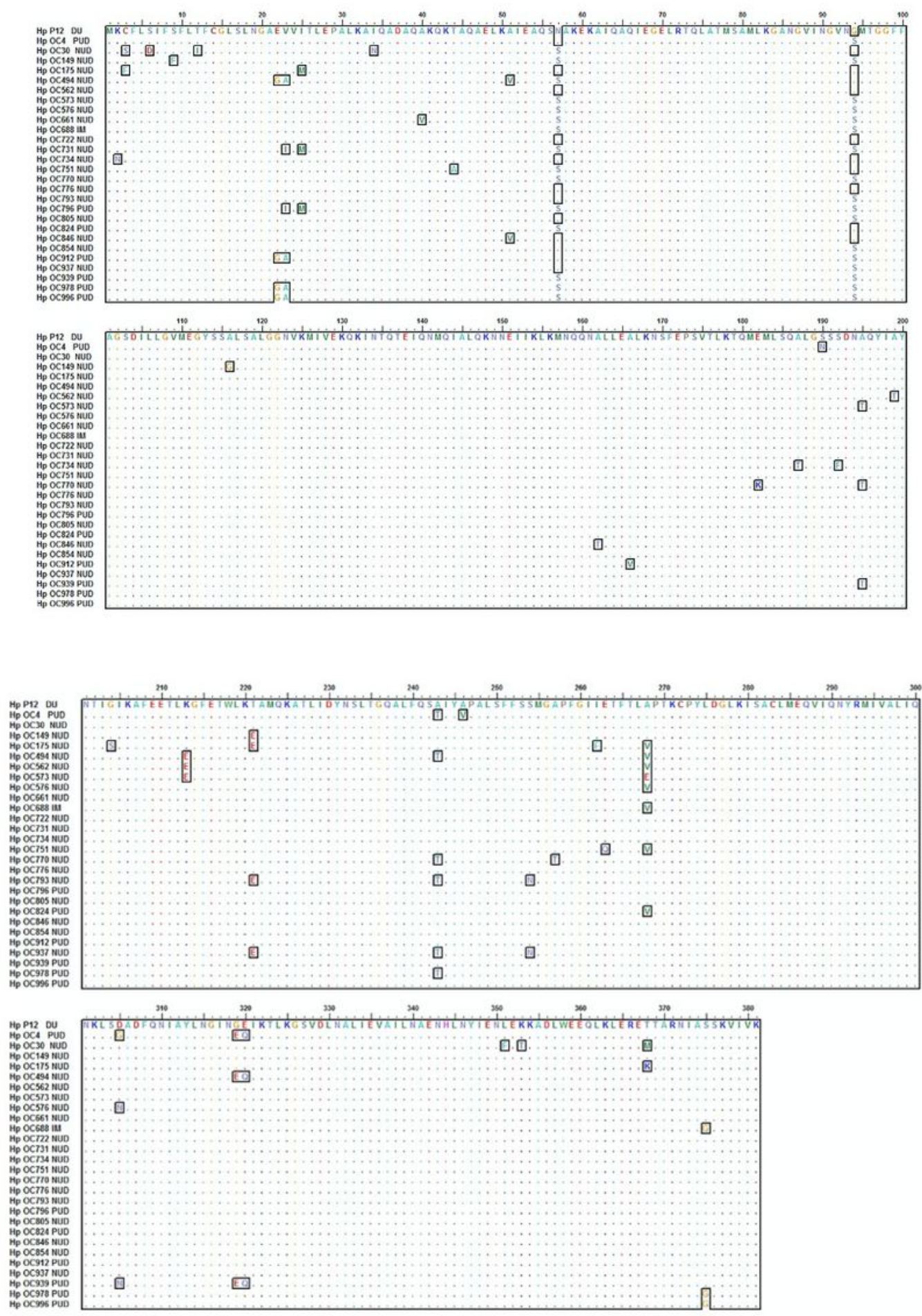

\section{Figure 1}

Complete alignment of Cagl sequences among $\mathrm{H}$. pylori strains $(n=27)$ from patients with different clinical status. The amino acid sequences were compared with the Cagl sequences of H. pylori strain P12 (is shown on the top line), as a reference strain. The variable and infrequent amino acid residues are 
surrounded by black borders. Notably, the C-terminal hexapeptide motif consisting of the SKVIVK sequence were highly conserved among the strains.
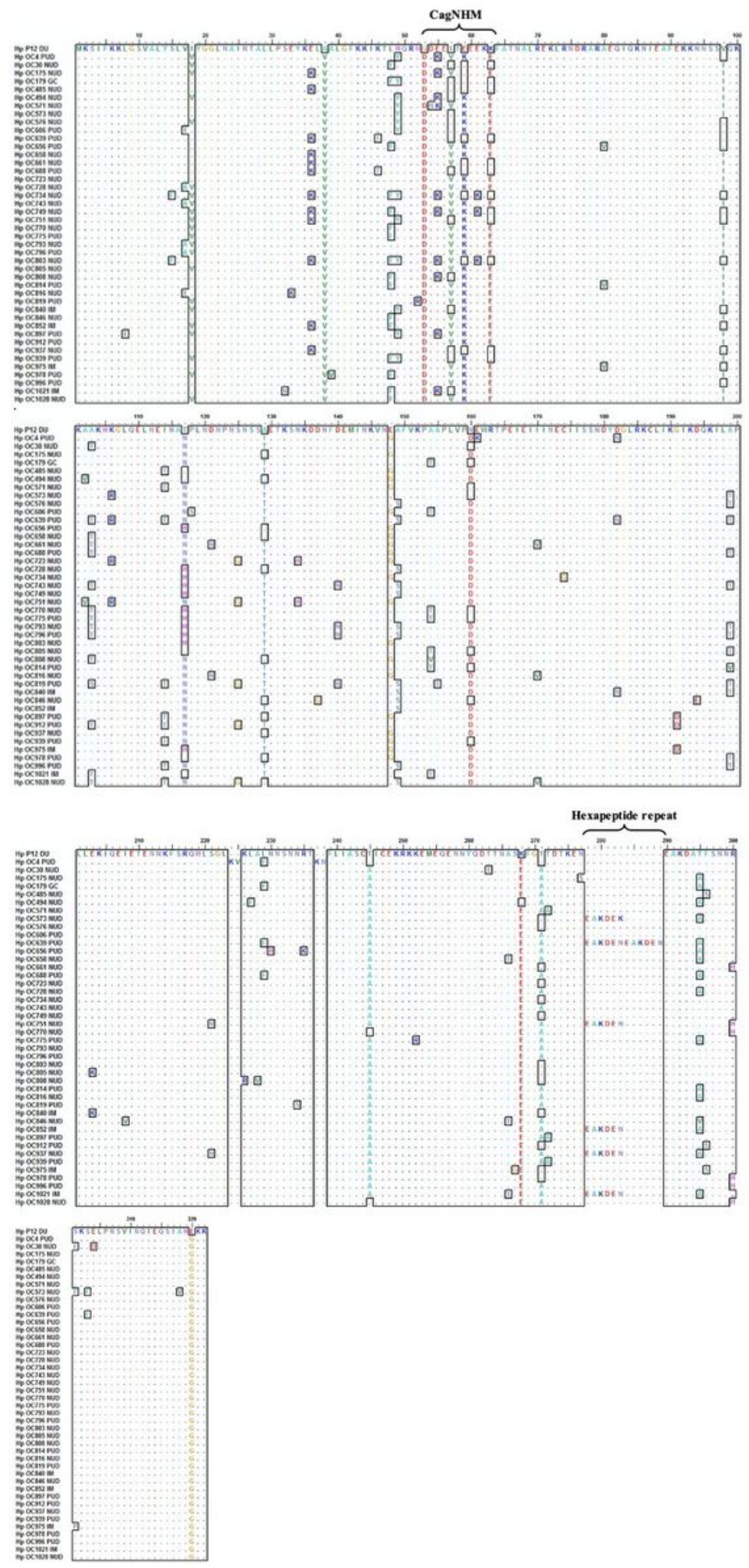

Figure 2

Complete alignment of CagN sequences among $43 \mathrm{H}$. pylori strains from patients with different clinical status. The amino acid sequences were compared with the $\mathrm{CagN}$ sequences of $\mathrm{H}$. pylori strain $\mathrm{P} 12$ (is shown on the top line), as a reference strain. The variable and infrequent amino acid residues are 
surrounded by black borders. Notably, the CagN hypervariable motif (CagNHM) and the conserved hypothetical hexapeptide repeat (EAKDEN/K) are indicated at residues 53-63 and 278-283, respectively.

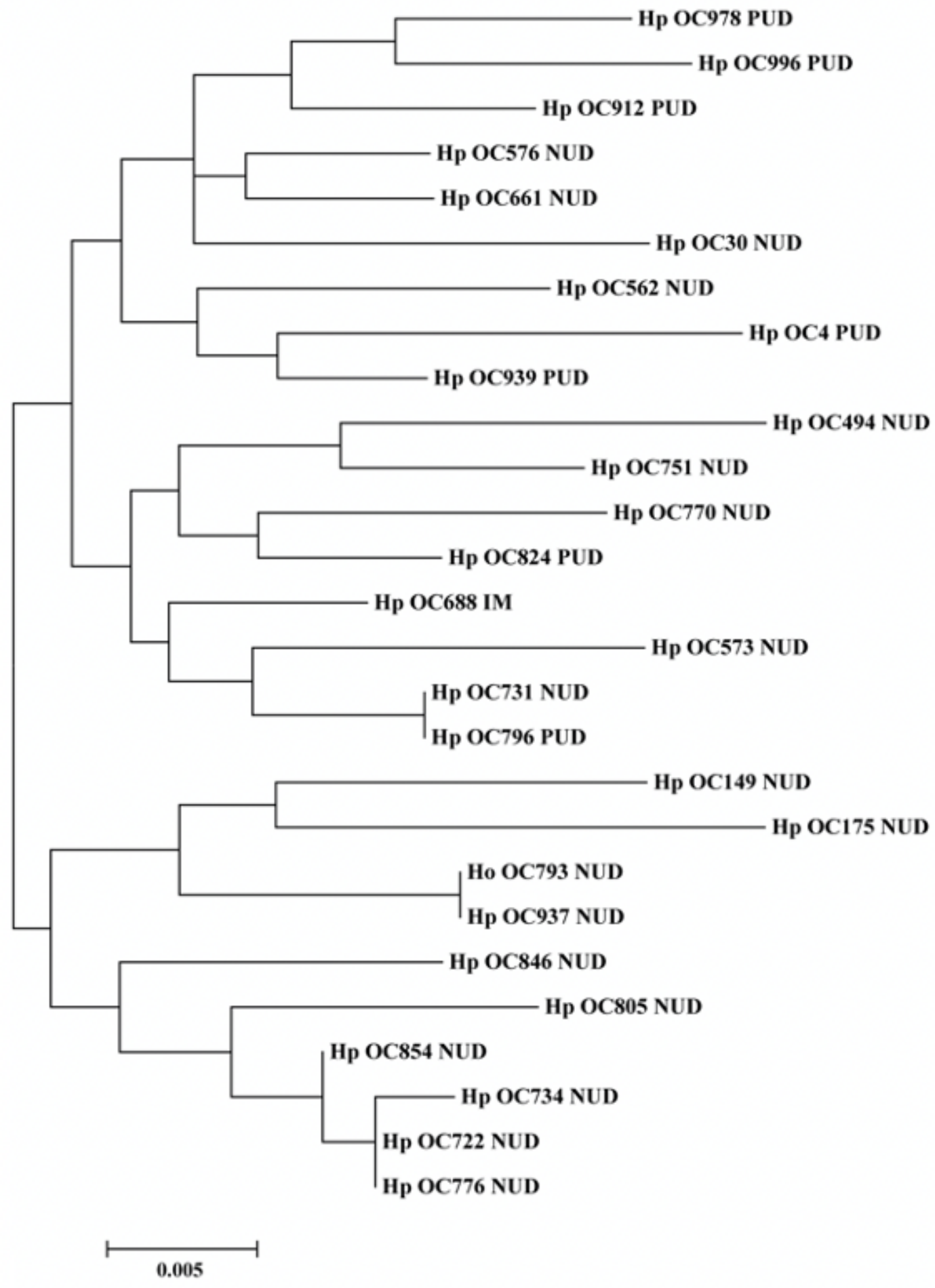

Figure 3

Phylogenetic tree of H. pylori clinical strains $(n=27)$ based on cagl nucleotide sequences. Maximum likelihood tree of concatenated sequences was constructed using MEGA7 software with bootstrap 
method at 1000 replications. The evolutionary distances were computed using the Tamura 3-parameter model.

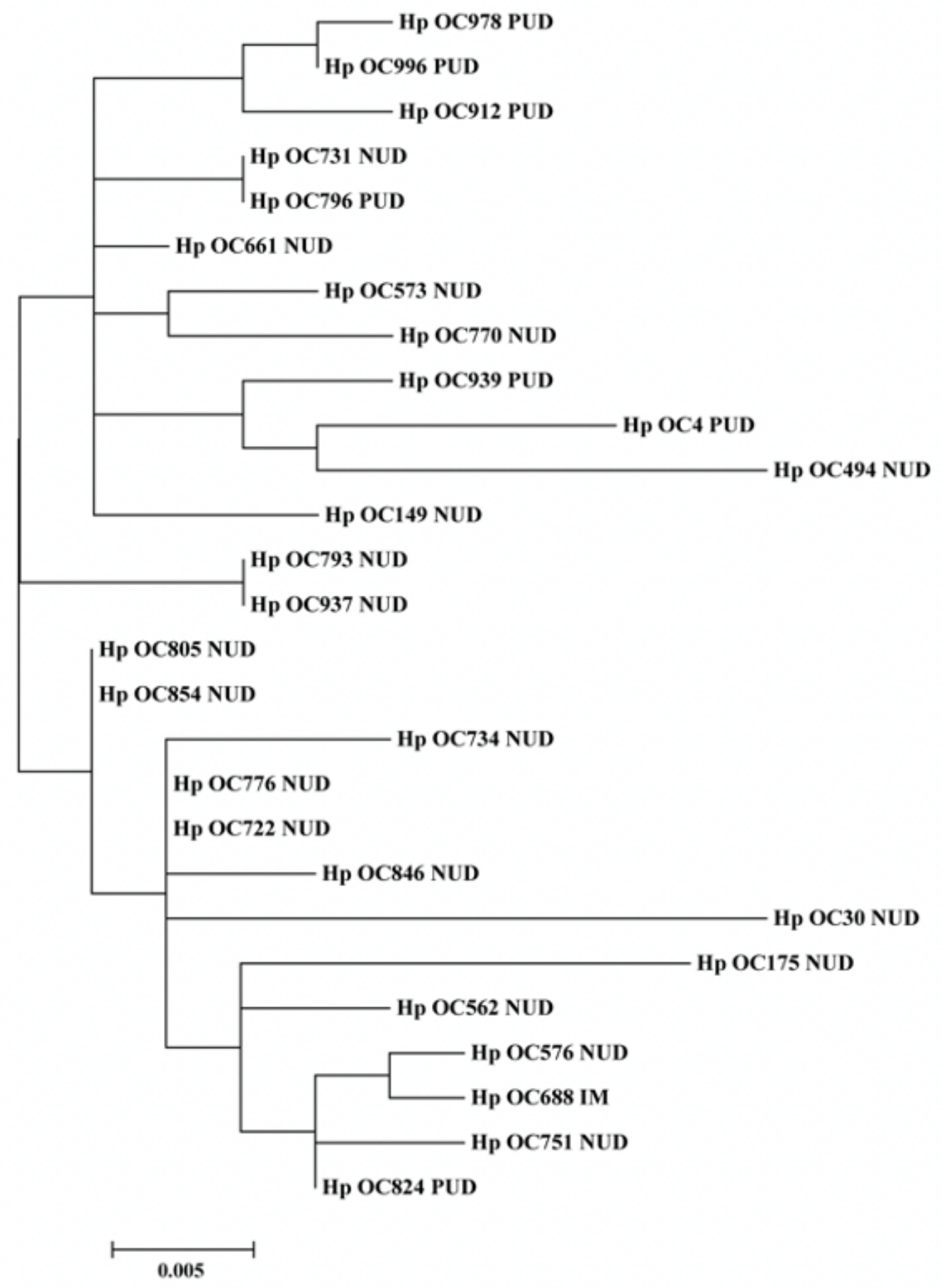

Figure 4

Phylogenetic tree of $\mathrm{H}$. pylori clinical strains $(\mathrm{n}=27)$ based on translated Cagl amino acid sequences. Maximum likelihood tree of concatenated sequences was constructed using MEGA7 software with 
bootstrap method at 1000 replications. The evolutionary distances were computed using the Poisson correction method.

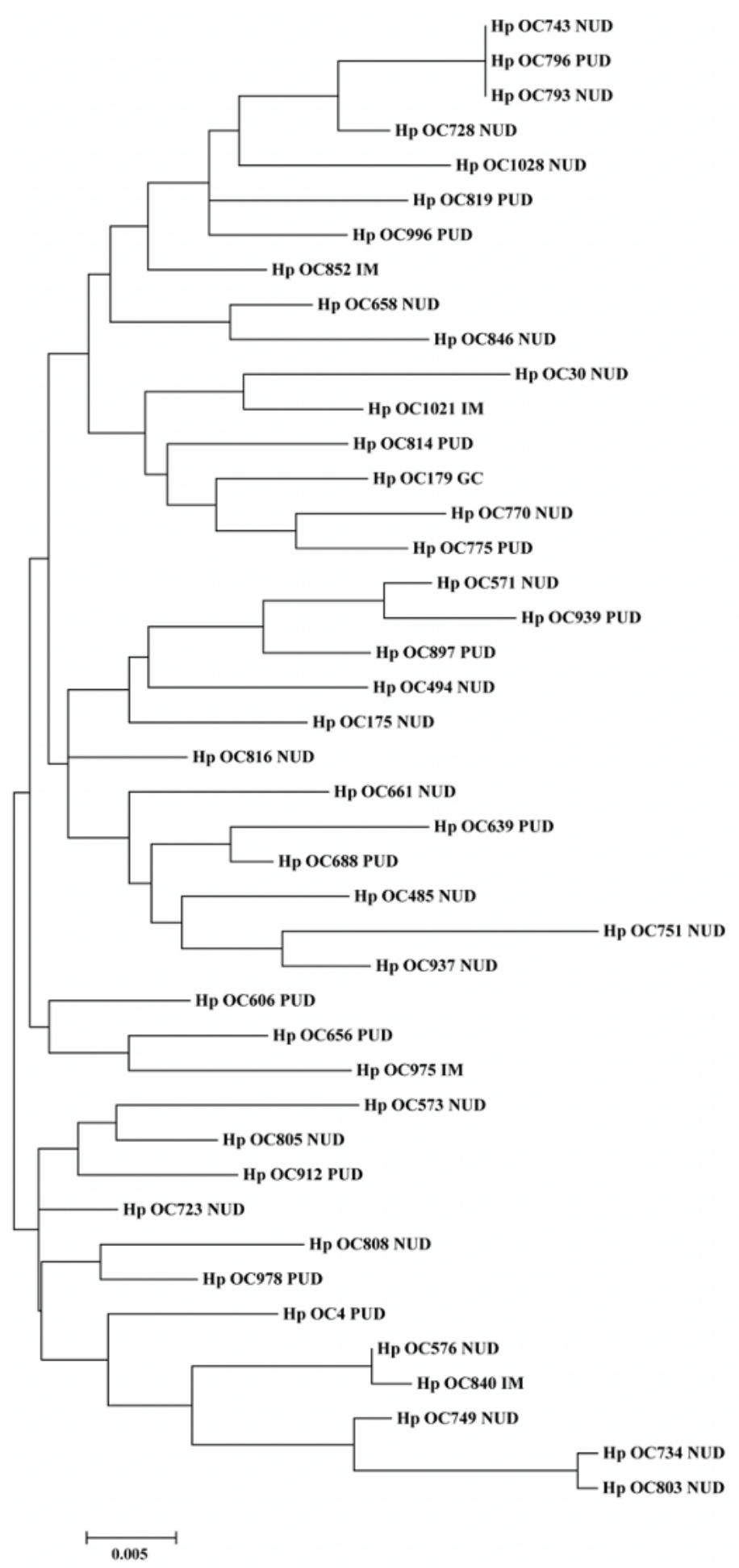

\section{Figure 5}

Phylogenetic tree of $\mathrm{H}$. pylori clinical strains $(n=43)$ based on cagN nucleotide sequences. Maximum likelihood tree of concatenated sequences was constructed using MEGA7 software with bootstrap 
method at 1000 replications. The evolutionary distances were computed using the Tamura 3-parameter model.

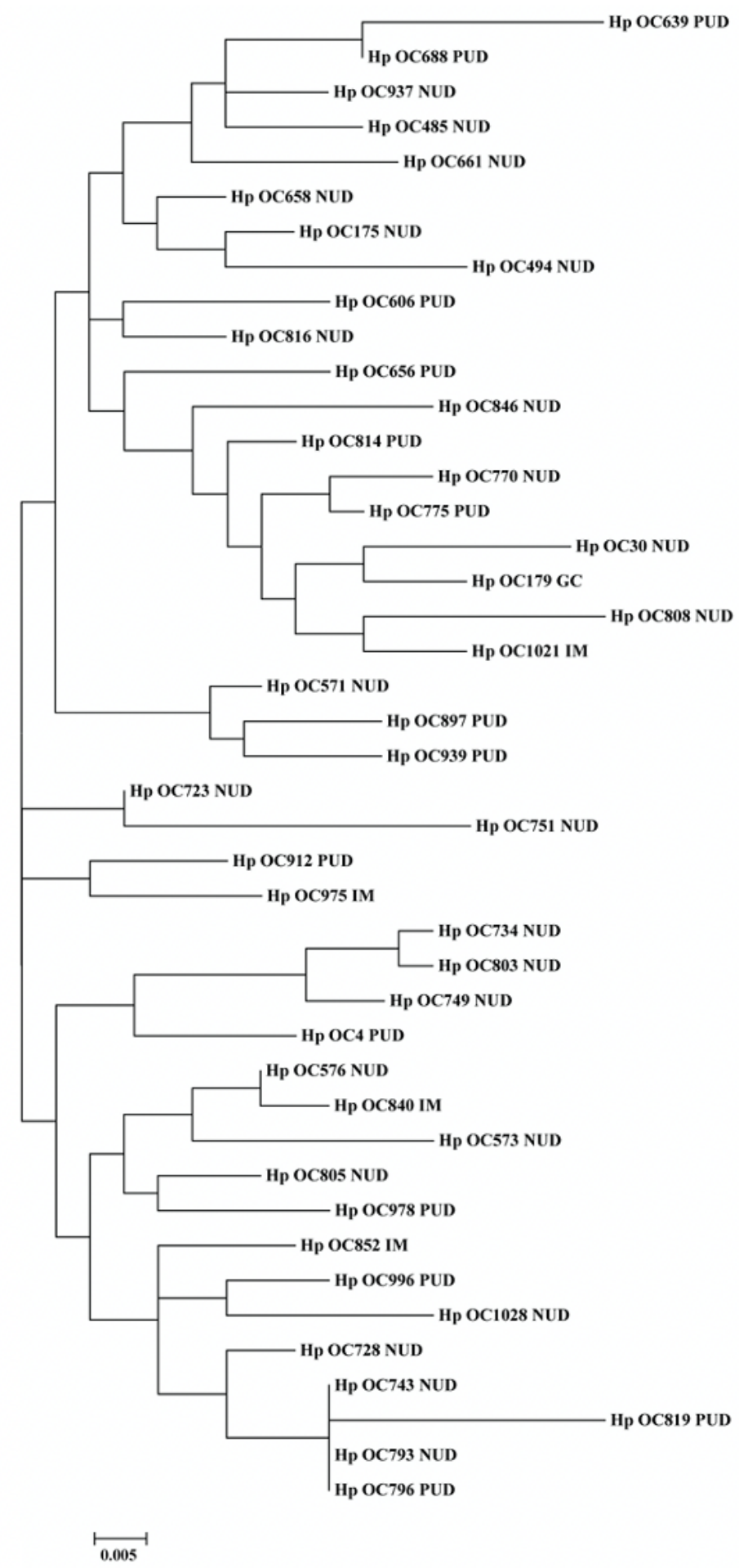

Figure 6

Phylogenetic tree of $\mathrm{H}$. pylori clinical strains $(\mathrm{n}=43)$ based on translated CagN amino acid sequences. Maximum likelihood tree of concatenated sequences was constructed using MEGA7 software with 
bootstrap method at 1000 replications. The evolutionary distances were computed using the Poisson correction method. 